\title{
The patterns and implications of diurnal variations in the d-excess of plant water, shallow soil water and air moisture
}

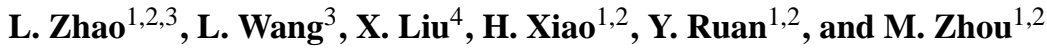 \\ ${ }^{1}$ Key Laboratory of Ecohydrology and Integrated River Basin Science, Cold and Arid Regions Environmental and \\ Engineering Research Institute, Chinese Academy of Sciences, Lanzhou 730000, China \\ ${ }^{2}$ Key Laboratory of Heihe Ecohydrology and Basin Science of Gansu Province, Lanzhou 730000, China \\ ${ }^{3}$ Department of Earth Sciences, Indiana University-Purdue University Indianapolis (IUPUI), Indianapolis, IN 46202, USA \\ ${ }^{4}$ State Key Laboratory of Cryospheric Sciences, Cold and Arid Regions Environmental and Engineering Research Institute, \\ Chinese Academy of Sciences, Lanzhou 730000, China
}

Correspondence to: L. Wang (wang.iupui@gmail.com)

Received: 4 April 2014 - Published in Hydrol. Earth Syst. Sci. Discuss.: 28 April 2014

Revised: 4 September 2014 - Accepted: 9 September 2014 - Published: 17 October 2014

\begin{abstract}
Deuterium excess (d-excess) of air moisture is traditionally considered a conservative tracer of oceanic evaporation conditions. Recent studies challenge this view and emphasize the importance of vegetation activity in controlling the dynamics of air moisture d-excess. However, direct field observations supporting the role of vegetation in d-excess variations are not well documented. In this study, we quantified the d-excess of air moisture, shallow soil water $(5$ and $10 \mathrm{~cm})$ and plant water (leaf, root and xylem) of multiple dominant species at hourly intervals during three extensive field campaigns at two climatically different locations within the Heihe River basin, northwestern China. The ecosystems at the two locations range from forest to desert. The results showed that with the increase in temperature $(T)$ and the decrease in relative humidity $(\mathrm{RH})$, the $\delta \mathrm{D}-\delta^{18} \mathrm{O}$ regression lines of leaf water, xylem water and shallow soil water deviated gradually from their corresponding local meteoric water line. There were significant differences in d-excess values between different water pools at all the study sites. The most positive d-excess values were found in air moisture $(9.3 \% o)$ and the most negative d-excess values were found in leaf water $(-85.6 \%$ ). The d-excess values of air moisture $\left(d_{\text {moisture }}\right)$ and leaf water $\left(d_{\text {leaf }}\right)$ during the sunny days, and shallow soil water $\left(d_{\text {soil }}\right)$ during the first sunny day after a rain event, showed strong diurnal patterns. There were significantly positive relationships between $d_{\text {leaf }}$ and RH and negative relationships between $d_{\text {moisture }}$ and RH. The correlations of $d_{\text {leaf }}$ and $d_{\text {moisture with } T \text { were opposite to their }}$
\end{abstract}

relationships with RH. In addition, we found opposite diurnal variations for $d_{\text {leaf }}$ and $d_{\text {moisture }}$ during the sunny days, and for $d_{\text {soil }}$ and $d_{\text {moisture }}$ during the first sunny day after the rain event. The steady-state Craig-Gordon model captured the diurnal variations in $d_{\text {leaf }}$, with small discrepancies in the magnitude. Overall, this study provides a comprehensive and high-resolution data set of d-excess of air moisture, leaf, root, xylem and soil water. Our results provide direct evidence that $d_{\text {moisture }}$ of the surface air at continental locations can be significantly altered by local processes, especially plant transpiration during sunny days. The influence of shallow soil water on $d_{\text {moisture }}$ is generally much smaller compared with that of plant transpiration, but the influence could be large on a sunny day right after rainfall events.

\section{Introduction}

Measurements of water isotopic compositions (e.g., $\delta \mathrm{D}$, $\delta^{18} \mathrm{O}$ ) provide insights into the study of hydrologic cycles, ecological processes, and palaeoclimates across multiple temporal and spatial scales (e.g., Brunel et al., 1992; Gat, 1996; Dawson et al., 2002; Newman et al., 2010; Wang et al., 2010, 2013, 2014; Zhang et al., 2011; Good et al., 2012). Plant uptake does not fractionate source water (White et al., $1985), \delta \mathrm{D}$ or $\delta^{18} \mathrm{O}$, and therefore can be used to track a plant water source (Ehleringer and Dawson, 1992), to investigate relative rooting depth (Jackson et al., 1999), and to identify 
hydraulic redistribution (Dawson, 1993). Water isotopes can also be used to trace catchment water movements (Brooks et al., 2010), the geographic origin of water vapor (Clark and Fritz, 1997), basin-level water recycling (Salati et al., 1979), and to reconstruct past environmental parameters such as ambient temperature $(T)$ and relative humidity $(\mathrm{RH})$ (e.g., Helliker and Richter, 2008). The isotopic compositions of water from different areas are affected by specific meteorological processes, which provide a characteristic fingerprint of their origin (Clark and Fritz, 1997). Much work has focused on isotopic compositions of surface water (Zhao et al., 2011b), groundwater (Zhao et al., 2012) and precipitation (Dalai et al., 2002; Karim and Veizer, 2002; Zhao et al., 2011b; Soderberg et al., 2013). However, fewer investigations were conducted to measure simultaneously $\delta \mathrm{D}$ and $\delta^{18} \mathrm{O}$ of leaf water, xylem water, shallow soil water and air moisture, especially on the diurnal variations in these pools at ecosystem scale.

Deuterium excess (d-excess) is defined as d-excess $=\delta \mathrm{D}-$ $8.0 \times \delta^{18} \mathrm{O}$ (Dansgaard, 1964). Points that fall on the global meteoric water line (GMWL) have a constant d-excess of $10.0 \%$. This is because rainout isotopic fractionation is considered an equilibrium process, which affects the position of the data points on the GMWL, but which does not affect the intercept - d-excess. Since the effect of equilibrium Rayleigh condensation processes roughly follows the GMWL slope of 8, variations in d-excess can provide information about the environmental conditions (e.g., RH and $T$ ) during non-equilibrium processes in oceanic moisture source regions. In other words, d-excess is considered a conservative tracer of oceanic evaporation conditions, assuming there are no contributions from surface evapotranspiration as the air mass travels over land (Welp et al., 2012). Therefore, dexcess is used to identify the location of a moisture source when there are no contributions from surface evapotranspiration (Uemura et al., 2008). Transpiration does not change source water d-excess, since transpiration does not fractionate source water. Evaporation, however, usually results in a higher d-excess value (Gat et al., 1994). d-excess has been used to estimate evaporation in previous studies. For example, d-excess was used to quantify sub-cloud evaporation in Alpine regions (Froehlich et al., 2008) and to estimate the contribution of evaporation from the Great Lakes to the continental atmosphere (Gat et al., 1994).

By using a meta-analysis approach to synthesize d-excess measurements from multiple sites, Welp et al. (2012) showed that the d-excess value of surface atmospheric vapor can be significantly altered by local processes and that it is not a conserved tracer of humidity from the marine moisture source region, as previously assumed. In addition, modeling simulations also showed that plant transpiration plays an important role in diurnal d-excess variations (Welp et al., 2012), which contradicts the conventional understanding. Based on isotopic observations from a US Pacific Northwest temperate forest and a modeling exercise, Lai and Ehleringer (2011) concluded that atmospheric entrainment appears to drive the isotopic variation in water vapor in the early morning when the convective boundary layer develops rapidly, while evapotranspiration becomes more important in mid-afternoon as a primary moisture source of water vapor in the studied forest. These authors therefore also cast some doubts on whether continental water vapor d-excess can be used as a conserved tracer of environmental conditions during evaporation at the moisture source. Despite this new understanding of biological and environmental controls on d-excess variations, field observations of the role of the direct vegetation effect on diurnal d-excess variations are not readily seen in the literature. In addition, Merlivat and Jouzel (1979), one of the few who theoretically calculated the quantitative relationship between the d-excess of evaporating vapor with $T$ and RH, predicted that d-excess is affected by both $T$ and $\mathrm{RH}$, and the dexcess of evaporating vapor increases with $T\left(0.35 \% 0^{\circ} \mathrm{C}^{-1}\right)$, but decreases with RH $\left(-0.43 \% \circ \%^{-1}\right)$ (Merlivat and Jouzel, 1979). Field testing of such a theoretical relationship is lacking. The quantitative relationship will enhance our prediction of climatic and environmental change impact (e.g., changes in $T, \mathrm{RH}$, rainfall and location) on water cycles. Furthermore, it is unclear whether a consistent d-excess-RH relationship, similar to the d-excess-RH relationship of ocean evaporation, exists in evapotranspiration. Evapotranspiration from the earth's surface is a key process in the hydrological cycle connecting the earth's surface and the atmosphere. Therefore, it is essential to study the evapotranspiration process and its link to the atmospheric circulation in order to understand the feedbacks between the earth's surface and the atmosphere better (Aemisegger et al., 2013).

In this study, we quantified the d-excess dynamics of air moisture, shallow soil water $(5$ and $10 \mathrm{~cm}$ ), and leaf and xylem water of multiple dominant species at hourly intervals during three extensive field campaigns at two climatically different locations in the Heihe River basin, China. We aim to provide a field-based fine-resolution d-excess record and to explore the underlying mechanisms. The questions we addressed in this study are the following: (1) what are the diurnal patterns of d-excess in air moisture, leaves, roots, xylem and shallow soil water under different climatic and meteorological conditions? (2) What are the mechanisms of the observed patterns and their controlling factors? (3) How well do the widely used steady-state models capture the leaf d-excess dynamics?

\section{Materials and methods}

\subsection{Sampling sites}

The field sampling took place at two locations (Dayekou and Ejin) with distinct climatic conditions within the Heihe River basin (HRB), northwestern China (Fig. 1). The temperature is lowest in January, and is highest in July in both Dayekou (Zhao et al., 2011a) and Ejin. Dayekou is located 


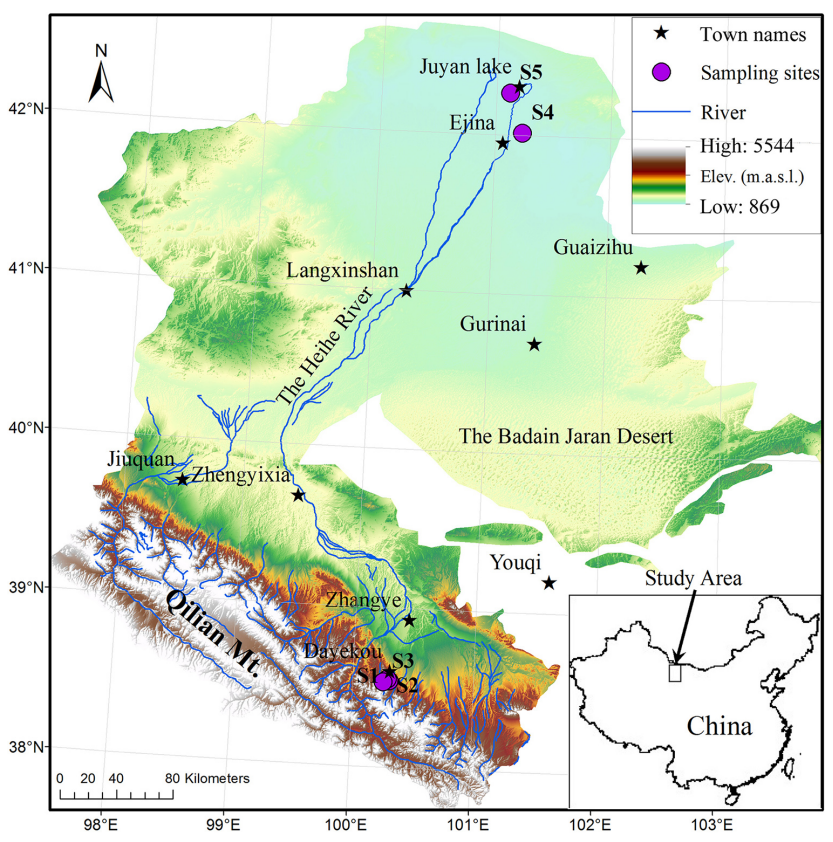

Figure 1. Locations of the sampling sites in the Heihe River basin. Note: the information about sampling locations, altitude, period of sampling and climatic conditions is listed in Table 1.

in the upper reaches (Fig. 1). The mean annual temperature of Dayekou is about $0.7^{\circ} \mathrm{C}$, with a mean January temperature of $-12.9^{\circ} \mathrm{C}$ and a mean July temperature of $12.2^{\circ} \mathrm{C}$. The mean annual precipitation is $369.2 \mathrm{~mm}$, with over $71 \%$ of the rainfall occurring between June and September, and the rainfall in July is the highest. Ejin is located in the lower reaches (Fig. 1). The mean annual temperature of Ejin is $8.8^{\circ} \mathrm{C}$, with a mean January temperature of $-11.3^{\circ} \mathrm{C}$ and a mean July temperature of $26.8^{\circ} \mathrm{C}$. The mean annual precipitation from 1960 to 2007 was $35.0 \mathrm{~mm}$ year $^{-1}$, with $75 \%$ of the rainfall occurring between June and September. With a strong potential evapotranspiration of $3700 \mathrm{~mm}$ (Gong et al., 2002), Ejin is considered one of the driest regions in China. At Dayekou, three sites were selected, with two sites (S1-Sep/S1-Jun and S2-Jun) in the Pailugou valley and the other (S3-Aug) in the Guantan valley. The site names were assigned based on a combination of location and sampling time. S1 $\left(100^{\circ} 18^{\prime} \mathrm{E}, 38^{\circ} 33^{\prime} \mathrm{N}, 2900 \mathrm{~m}\right)$ was dominated by tree species: Qinghai spruce (Q.S.), shrub species Potentilla fruticosa (P.F.), and grass species Polygonum viviparum (P.V.). S2 $\left(100^{\circ} 17^{\prime} \mathrm{E}, 38^{\circ} 33^{\prime} \mathrm{N}, 2700 \mathrm{~m}\right)$ was dominated by tree species Q.S. and grass species Stipa capillata (S.C.). S3 $\left(100^{\circ} 15^{\prime} \mathrm{E}, 38^{\circ} 32^{\prime} \mathrm{N}, 2800 \mathrm{~m}\right)$ was dominated by tree species Q.S. Two sites were selected at Ejin: one is in the riparian forest (S4-Aug: $101^{\circ} 14^{\prime} \mathrm{E}, 42^{\circ} 01^{\prime} \mathrm{N}, 930 \mathrm{~m}$ ) with the dominant tree species Populus euphratica (P.E.) and the shrub species Sophora alopecuroides (S.A.); the other is in the Gobi (S5-Aug: $101^{\circ} 07^{\prime} \mathrm{E}, 42^{\circ} 16^{\prime} \mathrm{N}, 906 \mathrm{~m}$ ), with the main shrub species Reaumuria soongorica (R.S.) (Table 1).

\subsection{Plant and soil sample collections}

Three extensive field samplings were conducted in August 2009 and in June and September 2011 in the upper and lower reaches of the HRB (Table 1). In the upper reaches, at S1-Jun, samples were taken from 06:00 LT (unless otherwise stated, all times hereafter are in local time), 23 June to $18: 00,25$ June 2011 at 1-hour intervals for leaves and stems of Q.S., 5 and $10 \mathrm{~cm}$ soil as well as atmospheric vapor near the ground (about $20 \mathrm{~cm}$ above the ground) and at the canopy. Leaves and stems of P.F. as well as leaves and roots of P.V. were taken from the same period at 2-hour intervals. All these samples were referred to as S1-Jun. At S1Sep, samples were taken from 08:00, 6 September to 17:00, 8 September 2011 at 1-hour intervals for leaves and stems of Q.S., 5 and $10 \mathrm{~cm}$ soil and atmospheric vapor near the ground and at the canopy. Leaves and stems of P.F. as well as leaves and roots of P.V. were taken from the same period at 2-hour intervals. At S2-Jun, leaves and stems of Q.S., 5 and $10 \mathrm{~cm}$ soil and atmospheric vapor near the ground and at the canopy were sampled from 06:00, 27 June to 18:00, 28 June 2011 at 1-hour intervals, while leaves and roots of S.C. were taken from 06:00, 27 June to 18:00, 28 June 2011 at 2-hour intervals. At S3-Aug, it rained twice during the sampling period (from 17:00, 31 July to 04:00, 1 August and from 10:40 to 20:00, 2 August 2009). Leaves and stems of Q.S. as well as 5 and $10 \mathrm{~cm}$ soil samples were taken from 06:00, 1 August to 18:00, 2 August and from 06:00 to 18:00, 3 August 2009 at 2-hour intervals. The atmospheric vapor at the canopy was collected from 06:00, 2 August to 18:00, 3 August 2009 at 2-hour intervals (Table 1).

In the lower reaches of the HRB, at S4-Aug, a leaf and stem of P.E. and a leaf of S.A., $10 \mathrm{~cm}$ soil and atmospheric vapor at the canopy were taken from 06:00, 6 August to 22:00, 9 August 2009 at 2-hour intervals. At S5-Aug, a leaf and stem of R.S., $10 \mathrm{~cm}$ soil and atmospheric vapor at the canopy were taken from 18:00, 10 August to 18:00, $12 \mathrm{Au}-$ gust 2009 at 2-hour intervals. When samples were taken during rainy days and mornings, napkins were used to wipe off water from the leaf and stem surfaces (Table 1).

For the soil, leaf and stem samples, samples from two $8 \mathrm{~mL}$ bottles were used to extract water and measure $\delta \mathrm{D}$ and $\delta^{18} \mathrm{O}$. All samples were frozen in the Linze and Ejin field stations right after sampling and then transferred back to the laboratory for water extraction. Water samples were extracted from leaves, stems, roots and soil by a cryogenic vacuum distillation line (Zhao et al., 2011b). The extracted water was frozen in a collection tube.

\subsection{Air moisture collection}

We used a method similar to Wang and Yakir (2000) for short-term sampling of ambient air moisture at different locations, such as Qinghai spruce forest (S1-Sep, S1-Jun, S2Jun and S3-Aug) in the upper reaches, and riparian forest 
Table 1. The vegetation types, sampling dates and time, and sampling types at the sampling sites in the Heihe River basin.

\begin{tabular}{|c|c|c|c|c|c|c|}
\hline $\begin{array}{l}\text { Study } \\
\text { region }\end{array}$ & $\begin{array}{l}\text { Ecosystem } \\
\text { type }\end{array}$ & Altitude (m) & Location ID & $\begin{array}{l}\text { Sampling time and } \\
\text { interval }\end{array}$ & Meteorological conditions & Sampling types \\
\hline \multirow[t]{6}{*}{$\begin{array}{l}\text { The upper } \\
\text { reaches }\end{array}$} & \multirow[t]{2}{*}{ Forest } & \multirow[t]{2}{*}{$2900 \mathrm{~m}$} & \multirow[t]{2}{*}{$\begin{array}{l}\text { S1-Sep: } \\
\text { Pailugou }\end{array}$} & $\begin{array}{l}6-8 \text { September } 2011 \\
1 \mathrm{~h} \text { interval }\end{array}$ & \multirow[t]{2}{*}{$\begin{array}{l}\text { The cloudy day: } 6 \text { September } 2011 \\
\text { The sunny day: } 7 \text { and } 8 \text { September } \\
2011\end{array}$} & $\begin{array}{l}\text { Qinghai spruce - leaf and stem } \\
5 \mathrm{~cm} \text { soil water } \\
10 \mathrm{~cm} \text { soil water } \\
\text { Atmospheric vapor near the ground } \\
\text { Atmospheric vapor at the canopy }\end{array}$ \\
\hline & & & & $\begin{array}{l}6-8 \text { September } 2011 \\
2 \mathrm{~h} \text { interval }\end{array}$ & & $\begin{array}{l}\text { Potentilla fruticosa - leaf and stem } \\
\text { Polygonum viviparum - leaf and root }\end{array}$ \\
\hline & \multirow[t]{2}{*}{ Forest } & \multirow[t]{2}{*}{$2900 \mathrm{~m}$} & $\begin{array}{l}\text { S1-Jun: } \\
\text { Pailugou }\end{array}$ & $\begin{array}{l}23-25 \text { June } 2011 \\
1 \mathrm{~h} \text { interval }\end{array}$ & \multirow[t]{2}{*}{$\begin{array}{l}\text { The sunny day: } 23 \text { June } 2011 \\
\text { The drizzly day: from 09:00 to } \\
\text { 20:00 on } 24 \text { June } 2011 \\
\text { The cloudy day: } 25 \text { June } 2011\end{array}$} & $\begin{array}{l}\text { Qinghai spruce - leaf and stem } \\
5 \mathrm{~cm} \text { soil water } \\
10 \mathrm{~cm} \text { soil water } \\
\text { Atmospheric vapor near the ground } \\
\text { Atmospheric vapor at the canopy }\end{array}$ \\
\hline & & & & $\begin{array}{l}23-25 \text { June } 2011 \\
2 \mathrm{~h} \text { interval }\end{array}$ & & $\begin{array}{l}\text { Potentilla fruticosa - leaf and stem } \\
\text { Polygonum viviparum - leaf and root }\end{array}$ \\
\hline & Forest & $2700 \mathrm{~m}$ & $\begin{array}{l}\text { S2-Jun: } \\
\text { Pailugou }\end{array}$ & $\begin{array}{l}27-28 \text { June } 011 \\
1 \mathrm{~h} \text { interval } \\
27-28 \text { June } 2011 \\
2 \mathrm{~h} \text { interval }\end{array}$ & $\begin{array}{l}\text { The sunny day: } 27 \text { June } 2011 \\
\text { The cloudy day: } 28 \text { June } 2011\end{array}$ & $\begin{array}{l}\text { Qinghai spruce - leaf and stem } \\
5 \mathrm{~cm} \text { soil water } \\
10 \mathrm{~cm} \text { soil water } \\
\text { Atmospheric vapor near the ground } \\
\text { Atmospheric vapor at the canopy } \\
\text { Stipa capillata - leaf and root }\end{array}$ \\
\hline & Forest & $2800 \mathrm{~m}$ & $\begin{array}{l}\text { S3-Aug: } \\
\text { Guantan }\end{array}$ & $\begin{array}{l}31 \text { July, 1-2 August } \\
2009 \\
2 \mathrm{~h} \text { interval }\end{array}$ & $\begin{array}{l}\text { Rain time: From 17:00, } 31 \text { July to } \\
\text { 04:00, } 1 \text { August } \\
\text { From 10:40 to } 22: 00,2 \text { August } 2009 \\
\text { The sunny day: } 1 \text { August }\end{array}$ & $\begin{array}{l}\text { Qinghai spruce - leaf and stem } \\
5 \mathrm{~cm} \text { soil water } \\
10 \mathrm{~cm} \text { soil water } \\
\text { Atmospheric vapor at the canopy }\end{array}$ \\
\hline \multirow[t]{2}{*}{$\begin{array}{l}\text { The lower } \\
\text { reaches }\end{array}$} & $\begin{array}{l}\text { Riparian } \\
\text { forest }\end{array}$ & $930 \mathrm{~m}$ & $\begin{array}{l}\text { S4-Aug: } \\
\text { Qidaoqiao }\end{array}$ & $\begin{array}{l}6-9 \text { August } 2009 \\
2 \mathrm{~h} \text { interval }\end{array}$ & The sunny day & $\begin{array}{l}\text { Populus euphratica - leaf and stem } \\
\text { Sophora alopecuroides - leaf } \\
10 \mathrm{~cm} \text { soil water } \\
\text { Atmospheric vapor at the canopy }\end{array}$ \\
\hline & Gobi & $906 \mathrm{~m}$ & $\begin{array}{l}\text { S5-Aug: } \\
\text { Gobi }\end{array}$ & $\begin{array}{l}10-12 \text { August } 2009 \\
2 \mathrm{~h} \text { interval }\end{array}$ & The sunny day & $\begin{array}{l}\text { Reaumuria soongorica - leaf and stem } \\
10 \mathrm{~cm} \text { soil water } \\
\text { Atmospheric vapor at the canopy }\end{array}$ \\
\hline
\end{tabular}

(S4-Aug) and the Gobi (S5-Aug) in the lower reaches. At S1-Sep, S1-Jun and S2-Jun, the samples of air moisture were collected within a canopy and near the ground (about $20 \mathrm{~cm}$ above the ground). At S3-Aug, S4-Aug and S5-Aug, the samples of air moisture were collected within a canopy (Fig. 1 and Table 1). Air was sucked by a small diaphragm pump through low-adsorption plastic tubes and a small cryogenic trap at $-80^{\circ} \mathrm{C}$ at a rate of about $250 \mathrm{~mL} \mathrm{~min}^{-1}$ for about $50 \mathrm{~min}$. Pump and traps were located on the ground downwind of the sampling site, and all the tubing was flushed with sample air before the actual trapping. After sampling, liquid water was transferred from traps to $2 \mathrm{~mL}$ glass bottles and transported to the laboratory for $\delta^{18} \mathrm{O}$ and $\delta \mathrm{D}$ analysis.

\subsection{Isotope analysis}

The $\delta^{18} \mathrm{O}$ and $\delta \mathrm{D}$ values of the water samples were measured using a Euro EA3000 element analyzer coupled to an Isoprime isotope ratio mass spectrometer (Isoprime Ltd, UK) at the Heihe Key Laboratory of Ecohydrology and River Basin Science, Cold and Arid Regions Environmental and Engineering Research Institute. To avoid the memory effect associated with continuous-flow methods, measurements of each sample were repeated five times, and the first values were discarded. The accuracy was better than $\pm 1.0 \%$ for $\delta \mathrm{D}$ and $\pm 0.2 \%$ for $\delta^{18} \mathrm{O}$. The $\delta^{18} \mathrm{O}$ and $\delta \mathrm{D}$ were calibrated using two international standard materials ( $V$-SMOW and GISP or $S L A P)$ and one working standard. The $\delta^{18} \mathrm{O}$ and $\delta \mathrm{D}$ values are expressed in \%o on a $V$-SMOW-SLAP scale.

\subsection{Meteorological measurements}

During each study period, RH, $T$ and photosynthetically available radiation (PAR) were measured due to their significant effects on soil evaporation and transpiration. At S3-Aug, $T, \mathrm{RH}$ and PAR were measured every $30 \mathrm{~min}$ with a weather station permanently installed at the station (HMP45C for measuring $T$ and RH, LI190SB for measuring PAR) at 2, 10 and $24 \mathrm{~m}$ in height. At S1-Sep, S1-Jun, S2-Jun, S4-Aug and S5-Aug, RH, T and PAR were measured every $10 \mathrm{~min}$ with a portable weather station (Davis Vantage Pro2 portable weather station) at $2 \mathrm{~m}$. Only $2 \mathrm{~m}$ height weather data such as $T, \mathrm{RH}$ and PAR were used in this study. 


\subsection{Modeling leaf water $\delta^{18} \mathrm{O}, \delta \mathrm{D}$ and d-excess}

Leaf water isotope enrichment is conventionally described by the steady-state Craig-Gordon equation (Craig and Gordon, 1965), and non-steady-state forms have also been proposed to account for the less enriched leaf water condition predicted by the steady-state model (e.g., Cuntz et al., 2007; Farquhar et al., 2007). To test whether we could use the current understanding of leaf water enrichment to reproduce the observed d-excess variations in leaf water, we used the steady-state Craig-Gordon model to estimate leaf water $\delta^{18} \mathrm{O}$ and $\delta \mathrm{D}$ values, and then calculated d-excess values using $\mathrm{d}$ excess $=\delta \mathrm{D}-8.0 \times \delta^{18} \mathrm{O}$ (Dansgaard, 1964). Only leaf water $\delta^{18} \mathrm{O}, \delta \mathrm{D}$ and d-excess values of P.E. at S5-Aug were modeled for this study, because it was sunny and had the most complete data set through that entire study period. The leaf water enrichment $\left(\delta_{1, \mathrm{~s}}\right)$ is calculated as

$\delta_{1, \mathrm{~s}} \approx \delta_{x}+\varepsilon_{\mathrm{eq}}+\varepsilon_{\mathrm{k}}+h\left(\delta_{v}-\varepsilon_{\mathrm{k}}-\delta_{x}\right)$,

where $\delta_{x}$ represents the $\delta^{18} \mathrm{O}$ or $\delta \mathrm{D}$ values of liquid water at the evaporating front. We estimated $\delta_{x}$ using the isotopic composition of xylem water. $\delta_{v}$ comprises the $\delta^{18} \mathrm{O}$ or $\delta \mathrm{D}$ values of the background atmospheric water vapor, $\alpha^{*}(>1)$ is the temperature-dependent equilibrium fractionation factor between liquid and vapor, $\varepsilon_{\text {eq }}$ equals $1000\left(1-1 / \alpha^{*}\right), \alpha_{\mathrm{k}}$ is the kinetic fractionation associated with diffusion of water through the soil, and $\varepsilon_{\mathrm{k}}$ equals $1000\left(\alpha_{\mathrm{k}}-1\right), 1.0189(\sim 19 \%$ o) for oxygen and $1.017(\sim 17 \%$ ) for hydrogen in a turbulent boundary layer (Wang and Yakir, 2000). $h$ is relative humidity normalized to the leaf temperature.

\section{Results}

\subsection{Meteorological conditions at each site during the sampling periods}

This study was conducted at the sites with dramatically different climatic conditions. The results showed that $\mathrm{T}, \mathrm{RH}$ and PAR varied significantly with the meteorological conditions and locations (Fig. 2). Low RH, high $T$ and PAR were found during the sunny days, whereas high $\mathrm{RH}$, low $T$ and PAR were found during the cloudy days at each site (Fig. 2). The RH decreased and $T$ increased from the upper reaches to the lower reaches, except at S2-Jun, with the lowest mean RH (42.2\%) (Table 2 and Fig. 2).

\subsection{Variations in $\delta^{18} \mathrm{O}$ and $\delta \mathrm{D}$ in different water pools}

Figure 3 shows the measured isotopic compositions of all the water samples in the $\delta \mathrm{D}-\delta^{18} \mathrm{O}$ plots. In general, the $\delta \mathrm{D}$ and $\delta^{18} \mathrm{O}$ of xylem and soil water showed relatively small ranges compared to those of leaf water and air moisture (Table 3 and Fig. 3). The $\delta \mathrm{D}$ and $\delta^{18} \mathrm{O}$ in leaf water varied from -37.6 to $44.0 \%$ and from -6.2 to $32.4 \%$, respectively, for all species. The $\delta \mathrm{D}$ and $\delta^{18} \mathrm{O}$ of air moisture at the canopy ranged from -188.9 to $-25.7 \%$ and from -24.9 to $-6.0 \%$, respectively, at all the study sites. The $\delta \mathrm{D}$ and $\delta^{18} \mathrm{O}$ of air moisture near the ground ranged from -133.0 to $-40.6 \%$ and from -19.7 to $-7.9 \%$, respectively, in the upper reaches. The $\delta \mathrm{D}$ and $\delta^{18} \mathrm{O}$ in xylem water (including stem and root) varied from -72.7 to $-21.4 \%$ and from -9.0 to $2.9 \%$, respectively. The $\delta \mathrm{D}$ and $\delta^{18} \mathrm{O}$ in soil water varied from -67.4 to $-6.3 \%$ and from -9.9 to $5.1 \%$, respectively (Table 3).

The air moisture had the lowest average $\delta \mathrm{D}$ and $\delta^{18} \mathrm{O}$ at all study sites that increased with rising altitude (Table 3 ). The $\delta \mathrm{D}-\delta^{18} \mathrm{O}$ regression lines were followed closely by the local meteoric water lines (LMWL) (Fig. 3). The average $\delta \mathrm{D}$ and $\delta^{18} \mathrm{O}$ of air moisture were -101.7 and $-14.1 \%$ near the ground, and were -99.1 and $-13.3 \%$ at the canopy, respectively, in the upper reaches. In the lower reaches, the average $\delta \mathrm{D}$ and $\delta^{18} \mathrm{O}$ of air moisture were -116.7 and $-16.2 \%$ at S4-Aug and -136.3 and $-17.7 \%$ at S5-Aug, respectively.

Leaf water had the highest average $\delta \mathrm{D}$ and $\delta^{18} \mathrm{O}$ values, leaf $\delta \mathrm{D}-\delta^{18} \mathrm{O}$ regression lines deviated highly from their corresponding LMWL, and leaf water showed the greatest variation in the observed $\delta^{18} \mathrm{O}$ values. In addition, leaf water $\delta \mathrm{D}$ and $\delta^{18} \mathrm{O}$ values increased with the decrease in altitude and the increase in $T$ (Tables 2 and 3). In the upper reaches, the average $\delta \mathrm{D}$ values in the leaf water of Q.S., P.F., P.V. and S.C. were $1.9,-5.6,-2.2$ and $10.4 \%$, respectively, and the average $\delta^{18} \mathrm{O}$ values were $8.3,3.0,1.5$ and $8.2 \%$, respectively. In the lower reaches, the average $\delta \mathrm{D}$ values in the leaf water of P.E., S.A. and R.S. were 6.2, 10.4 and $7.5 \%$, respectively, and the average $\delta^{18} \mathrm{O}$ values were $14.6,15.6$ and $27.2 \%$, respectively.

The average $\delta \mathrm{D}$ and $\delta^{18} \mathrm{O}$ values were -34.9 and $-4.2 \%$ o in $5 \mathrm{~cm}$ of soil water and -43.2 and $-5.2 \%$ in $10 \mathrm{~cm}$ of soil in the upper reaches, and -34.2 and $1.4 \%$ in $10 \mathrm{~cm}$ of water in the lower reaches, respectively. With the increase in $T$ and the decrease in altitude, the $\delta \mathrm{D}-\delta^{18} \mathrm{O}$ regression lines gradually deviated from their corresponding LMWL, and the variations in $\delta^{18} \mathrm{O}$ values in xylem and soil water also increased gradually (Tables 2 and 3). There were significant differences in $\delta \mathrm{D}$ and $\delta^{18} \mathrm{O}$ between xylem water of S.C. and $5 \mathrm{~cm}$ of soil water in the upper reaches. Differences were also seen in P.E. and R.S. in the lower reaches (Fig. 3 and Table 3).

\subsection{Variations in d-excess in each water pool}

\subsubsection{The diurnal variations in d-excess in leaf and xylem water during the sunny days}

Several sunny days were selected based on the meteorological record (Fig. 2). The selected periods included the following: from 06:00 to 18:00, 7 and 8 September at S1-Sep, from 06:00 to 16:00, 23 June at S1-Jun, from 06:00 to 16:00, 27 June at S2-Jun, from 06:00, 1 August to 16:00, 2 August and from 06:00 to 18:00, 3 August 2009 at S3-Aug. At S4-Aug and S5-Aug, all data were selected. The diurnal 

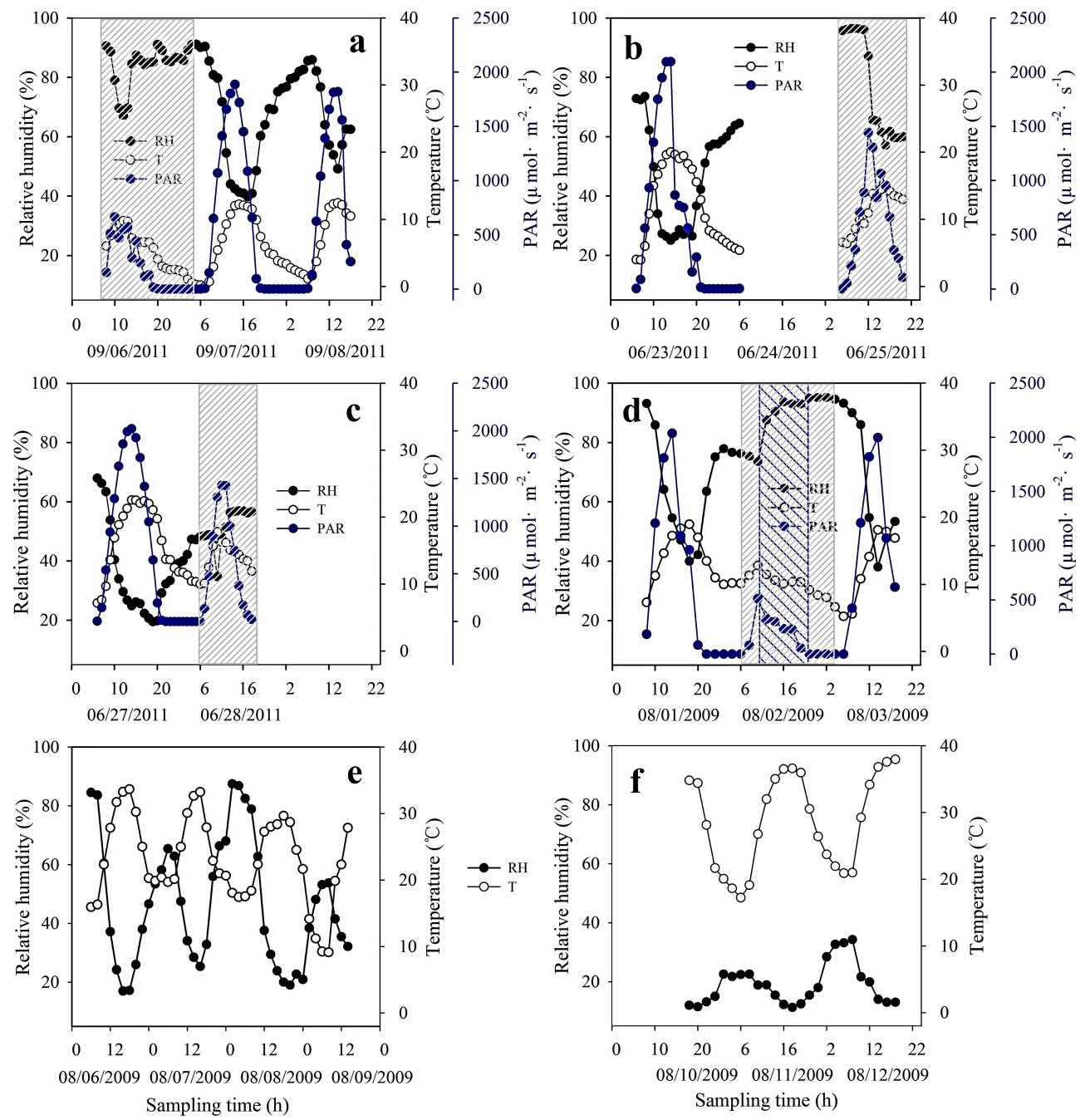

Figure 2. Comparison of hourly average relative humidity (RH), air temperature $(T)$ and photosynthetically active radiation (PAR) during the experimental period. The dark cycles and the white cycles indicate the RH and $T$ at each site. The grey shadow and the blue shadow (the one in panel d) indicate cloudy days and rainy days. Panels (a), (b), (c) and (d) refer to the Qinghai spruce forest of S1-Sep, S1-Jun, S2-Jun and S3-Aug. Panels (e) and (f) refer to S4-Aug and S5-Aug.

variations in leaf water d-excess $\left(d_{\text {leaf }}\right)$ and xylem water dexcess $\left(d_{\text {xylem }}\right)$ values during the sunny day were shown in Fig. 4. During the sunny days, we found clear and robust diurnal variations in $d_{\text {leaf }}$ at all the study sites. The maximum values of $d_{\text {leaf }}$ occurred from 06:00 to 10:00, gradually decreasing to a minimum value in the mid-afternoon (from 14:00 to 20:00), and increasing again to a maximum value from 04:00 to 08:00 on the next day (Fig. 4). In the upper reaches, the averaged $d_{\text {leaf }}$ values of Q.S. were $-64.7 \%$, and varied from $13.4 \%$ (S3-Aug) to $-133.8 \%$ (S2-Jun). The $d_{\text {leaf }}$ values of P.F. $(-29.8 \%)$ and P.V. $(-14.3 \%$ ) were higher than that of S.C. $(-55.4 \%)$. In the lower reaches, the mean $d_{\text {leaf }}$ value of P.E. $(-110.2 \%$ ) and S.A. $(-114.4 \%$ ) at S5-Aug were higher than that of R.S. $(-210.4 \%)$ at S4-Aug (Table 4).
The peak-to-trough amplitudes of $d_{\text {leaf }}$ varied greatly. They were $147.2 \%$ in trees (Q.S.), $122.6 \%$ in shrubs (P.F.), and ranged from $143.1 \%$ to $52.6 \%$ in grasses (P.V. and S.C.) in the upper reaches. In the lower reaches, the peak-to-trough amplitudes of $d_{\text {leaf }}$ were $124.4 \%$ in P.E. (tree), $96.9 \%$ in S.A. (shrub), and $80.6 \%$ in R.S. (shrub) (Table 4).

Compared to $d_{\text {leaf }}$, the diurnal variations in the $d_{\text {xylem }}$ of all species were more stable, and showed no clear diurnal variations (Fig. 4). In the upper reaches, the mean $d_{x y l e m}$ values of Q.S., P.F., P.V. and S.C. were 6.2, 0.8, 7.6 and $-18.8 \%$, respectively. The averaged differences between $d_{\text {xylem }}$ and $d_{\text {leaf }}$ were $70.9,30.6,21.9$ and $36.6 \%$ in Q.S., P.F., P.V. and S.C. in the upper reaches. In the lower reaches, the mean $d_{\text {xylem }}$ values of P.E. and R.S. were $-8.2 \%$ (S4-Aug) and $-44.8 \%$ (S5-Aug), and the differences between $d_{\text {xylem }}$ and 
Table 2. Meteorological data at each site during the observation periods. Note: S1-Sep, S1-Jun, S2-Jun and S3-Aug indicate the 2900 m Qinghai spruce forest site in September 2011, the $2900 \mathrm{~m}$ site in June 2011, the $2700 \mathrm{~m}$ site in June 2011 and the $2800 \mathrm{~m}$ site in August 2009 in the upper reaches. S4-Aug and S5-Aug indicate the riparian forest at $930 \mathrm{~m}$ and the Gobi site at $906 \mathrm{~m}$ in August 2009 in the lower reaches.

\begin{tabular}{|c|c|c|c|c|c|c|c|c|c|}
\hline & \multicolumn{3}{|c|}{ S1-Sep } & \multicolumn{3}{|c|}{ S1-Jun } & \multicolumn{3}{|c|}{ S2-Jun } \\
\hline & $\mathrm{RH}(\%)$ & $T\left({ }^{\circ} \mathrm{C}\right)$ & $\begin{array}{l}\text { PAR } \\
\left(\mu \mathrm{mol} \mathrm{m}{ }^{-2} \mathrm{~s}^{-1}\right)\end{array}$ & $\mathrm{RH}(\%)$ & $T\left({ }^{\circ} \mathrm{C}\right)$ & $\begin{array}{l}\text { PAR } \\
\left(\mu \mathrm{mol} \mathrm{m}{ }^{-2} \mathrm{~s}^{-1}\right)\end{array}$ & $\mathrm{RH}(\%)$ & $T\left({ }^{\circ} \mathrm{C}\right)$ & $\begin{array}{l}\text { PAR } \\
\left(\mu \mathrm{mol} \mathrm{m}{ }^{-2} \mathrm{~s}^{-1}\right)\end{array}$ \\
\hline Mean & 74.3 & 6.3 & 491.7 & 58.9 & 11.5 & 576.0 & 42.2 & 15.2 & 687.1 \\
\hline Minimum & 39.8 & 0.0 & 0.0 & 25.0 & 4.0 & 0.0 & 19.4 & 7.2 & 0.0 \\
\hline Maximum & 91.1 & 12.4 & 1886.0 & 96.5 & 20.0 & 2097.0 & 67.9 & 22.5 & 2021.0 \\
\hline \multirow[t]{3}{*}{ SD } & 15.5 & 3.9 & 637.6 & 21.9 & 5.0 & 625.9 & 14.3 & 4.5 & 713.1 \\
\hline & \multicolumn{3}{|c|}{ S3-Aug } & \multicolumn{3}{|c|}{ S4-Aug } & \multicolumn{3}{|c|}{ S5-Aug } \\
\hline & RH (\%) & $T\left({ }^{\circ} \mathrm{C}\right)$ & $\begin{array}{l}\text { PAR } \\
\left(\mu \mathrm{mol} \mathrm{m}{ }^{-2} \mathrm{~s}^{-1}\right)\end{array}$ & $\mathrm{RH}(\%)$ & $T\left({ }^{\circ} \mathrm{C}\right)$ & & RH (\%) & $T\left({ }^{\circ} \mathrm{C}\right)$ & \\
\hline Mean & 74.8 & 12.0 & 541.1 & 46.5 & 23.1 & & 19.0 & 28.7 & \\
\hline Minimum & 38.0 & 5.2 & 0.0 & 17.0 & 9.1 & & 11.3 & 17.2 & \\
\hline Maximum & 95.1 & 18.8 & 2036.0 & 87.5 & 33.7 & & 34.3 & 38.0 & \\
\hline SD & 19.4 & 4.0 & 676.5 & 21.6 & 6.5 & & 7.0 & 7.1 & \\
\hline
\end{tabular}

Table 3. Spatial and temporal variations in the $\delta^{18} \mathrm{O}$ and $\delta \mathrm{D}$ of different water pools in the Heihe River basin. The numbers in parentheses indicate the number of samples. In the upper reaches, Q.S., P.F., P.V. and S.C. refer to Qinghai spruce, Potentilla fruticosa, Polygonum viviparum and Stipa capillata in the forest ecosystem. In the lower reaches, P.E. and S.A. refer to Populus euphratica and Sophora alopecuroides in the riparian forest ecosystem. R.S. refers to Reaumuria soongorica at the Gobi site.

\begin{tabular}{|c|c|c|c|c|c|c|c|c|c|c|c|c|c|c|}
\hline \multirow{3}{*}{$\begin{array}{l}\text { Study sites } \\
\text { Plant species } \\
\text { Leaf water }\end{array}$} & \multicolumn{8}{|c|}{ S1-Sep, S1-Jun, S2-Jun and S3-Aug } & \multicolumn{4}{|c|}{ S4-Aug } & \multirow{2}{*}{\multicolumn{2}{|c|}{$\begin{array}{c}\text { S5-Aug } \\
\text { R.S. }(n=23)\end{array}$}} \\
\hline & \multicolumn{2}{|c|}{ Q.S. $(n=166)$} & \multicolumn{2}{|c|}{ P.F. $(n=51)$} & \multicolumn{2}{|c|}{ P.V. $(n=51)$} & \multicolumn{2}{|c|}{ S.C. $(n=23)$} & \multicolumn{2}{|c|}{ P.E. $(n=36)$} & \multicolumn{2}{|c|}{ S.A. $(n=36)$} & & \\
\hline & $\delta^{18} \mathrm{O}_{\text {leaf }}$ & $\delta \mathrm{D}_{\text {leaf }}$ & $\delta^{18} \mathrm{O}_{\text {leaf }}$ & $\delta \mathrm{D}_{\text {leaf }}$ & $\delta^{18} \mathrm{O}_{\text {leaf }}$ & $\delta \mathrm{D}_{\text {leaf }}$ & $\delta^{18} \mathrm{O}_{\text {leaf }}$ & $\delta \mathrm{D}_{\text {leaf }}$ & $\delta^{18} \mathrm{O}_{\text {leaf }}$ & $\delta \mathrm{D}_{\text {leaf }}$ & $\delta^{18} \mathrm{O}_{\text {leaf }}$ & $\delta \mathrm{D}_{\text {leaf }}$ & $\delta^{18} \mathrm{O}_{\text {leaf }}$ & $\delta \mathrm{D}_{\text {leaf }}$ \\
\hline Mean & 8.3 & 1.9 & 3.0 & -5.6 & 1.5 & -2.2 & 8.2 & 10.4 & 14.6 & 6.2 & 15.6 & 10.4 & 27.2 & 7.5 \\
\hline Minimum & -4.8 & -29.4 & -5.0 & -37.6 & -6.2 & -35.0 & 1.7 & -6.1 & 3.4 & -9.7 & 5.8 & -3.8 & 22.2 & -5.0 \\
\hline Maximum & 18.5 & 22.8 & 17.7 & 31.6 & 20.1 & 44.0 & 11.4 & 22.8 & 21.3 & 23.4 & 20.3 & 19.1 & 32.4 & 23.4 \\
\hline SD & 6.8 & 13.3 & 6.4 & 17.1 & 7.0 & 20.1 & 2.5 & 7.9 & 5.0 & 8.2 & 3.9 & 5.8 & 2.5 & 6.6 \\
\hline Xylem water & $\delta^{18} \mathrm{O}_{\text {xylem }}$ & $\delta \mathrm{D}_{\mathrm{xylem}}$ & $\delta^{18} \mathrm{O}_{\text {xylem }}$ & $\delta \mathrm{D}_{\text {xylem }}$ & $\delta^{18} \mathrm{O}_{\mathrm{xylem}}$ & $\delta \mathrm{D}_{\text {xylem }}$ & $\delta^{18} \mathrm{O}_{\text {xylem }}$ & $\delta \mathrm{D}_{\text {xylem }}$ & $\delta^{18} \mathrm{O}_{\text {xylem }}$ & $\delta \mathrm{D}_{\text {xylem }}$ & $\delta^{18} \mathrm{O}_{\text {leaf }}$ & $\delta \mathrm{D}_{\text {leaf }}$ & $\delta^{18} \mathrm{O}_{\text {xylem }}$ & $\delta \mathrm{D}_{\text {xylem }}$ \\
\hline Mean & -6.7 & -47.2 & -5.0 & -39.1 & -6.5 & -44.6 & -1.7 & -32.7 & -5.2 & -48.9 & - & - & -2.4 & -64.2 \\
\hline Minimum & -9.0 & -65.7 & -7.5 & -60.1 & -8.5 & -61.5 & -5.4 & -46.6 & -5.6 & -51.7 & - & - & -4.9 & -72.7 \\
\hline Maximum & -2.1 & -21.6 & -2.9 & -23.6 & -4.8 & -32.7 & 1.0 & -21.4 & -4.2 & -43.9 & - & - & 2.9 & -50.0 \\
\hline $\mathrm{SD}$ & 1.6 & 10.1 & 1.1 & 8.8 & 1.0 & 7.4 & 1.6 & 7.3 & 0.3 & 1.7 & - & - & 1.9 & 6.1 \\
\hline$\delta_{\text {xylem }}-\delta_{\text {leaf }}$ & -15.0 & -49.1 & -8.0 & -33.5 & -8.0 & -42.4 & -9.9 & -43.1 & -19.8 & $-\mathbf{5 5 . 1}$ & - & - & -29.6 & -71.7 \\
\hline \multirow[t]{2}{*}{ Soil water } & \multicolumn{4}{|c|}{5 cm depth $(n=166)$} & \multicolumn{4}{|c|}{$10 \mathrm{~cm}$ depth $(n=166)$} & \multicolumn{4}{|c|}{$10 \mathrm{~cm}$ depth $(n=36)$} & \multicolumn{2}{|c|}{$10 \mathrm{~cm}$ depth $(n=4)$} \\
\hline & \multicolumn{2}{|c|}{$\delta^{18} \mathrm{O}_{\text {soil }}$} & \multicolumn{2}{|c|}{$\delta \mathrm{D}_{\text {soil }}$} & \multicolumn{2}{|c|}{$\delta^{18} \mathrm{O}_{\text {soil }}$} & \multicolumn{2}{|c|}{$\delta \mathrm{D}_{\text {soil }}$} & \multicolumn{2}{|c|}{$\delta^{18} \mathrm{O}_{\text {soil }}$} & \multicolumn{2}{|c|}{$\delta \mathrm{D}_{\text {soil }}$} & $\delta^{18} \mathrm{O}_{\text {soil }}$ & $\delta \mathrm{D}_{\text {soil }}$ \\
\hline Mean & \multicolumn{2}{|c|}{-4.2} & \multicolumn{2}{|c|}{-34.9} & \multicolumn{2}{|c|}{-5.2} & \multicolumn{2}{|c|}{-43.2} & \multicolumn{2}{|c|}{0.0} & \multicolumn{2}{|c|}{-31.2} & 2.7 & -37.1 \\
\hline Minimum & \multicolumn{2}{|c|}{-8.9} & \multicolumn{2}{|c|}{-62.0} & -9 & & -67 & & -2 & & -36 & & 1.1 & -46.8 \\
\hline Maximum & 2. & & -6 & & -0 & & -12 & & 2. & & -21 & & 5.1 & -27.5 \\
\hline SD & 2. & & 10 & & 2.1 & & 10. & & 1. & & 3.3 & & 1.9 & 8.3 \\
\hline Air moisture & & the cano & $(n=172)$ & & & ar the gro & nd $(n=172)$ & & & the canop & $(n=36)$ & & At the cano & $y=23)$ \\
\hline & $\delta^{18} \mathrm{O}_{\mathrm{m}}$ & isture & $\delta \mathrm{D}_{\mathrm{mo}}$ & & $\delta^{18} \mathrm{O}_{\mathrm{mc}}$ & isture & $\delta \mathrm{D}_{\text {mois }}$ & sture & $\delta^{18} \mathrm{O}_{\mathrm{m}}$ & isture & $\delta \mathrm{D}_{\text {moi }}$ & & $\delta^{18} \mathrm{O}_{\text {moisture }}$ & $\delta \mathrm{D}_{\text {moisture }}$ \\
\hline Mean & -1 & & -99 & & -14 & & -101 & & -16 & & -110 & & -17.7 & -136.3 \\
\hline Minimum & -1 & & -13 & & -19 & & -133 & & -23 & & -167 & & -24.9 & -188.9 \\
\hline Maximum & -6 & & -25 & & -7 & & -40 & & -11 & & -78 & & -11.7 & -96.3 \\
\hline $\mathrm{SD}$ & 1. & & 17 & & 2.2 & & 16. & & 3. & & 22 & & 3.3 & 23.2 \\
\hline
\end{tabular}

$d_{\text {leaf }}$ were 102.2 and $165.6 \%$ or S4-Aug and S5-Aug in the lower reaches, respectively (Table 4).

\subsubsection{Variations in d-excess in soil water and air moisture during the sunny days}

The averaged soil water d-excess values of 5 and $10 \mathrm{~cm}\left(d_{\text {soil }}\right)$ were -0.9 and $-1.2 \%$, varying from $-37.3 \%$ (S2-Jun) to $14.3 \%$ (S1-Sep), and from $-25.7 \%$ (S2-Jun) to $16.6 \%$ (S1-Sep) in the upper reaches, respectively. At S4-Aug and
S5-Aug, the averaged $d_{\text {soil }}$ values of $10 \mathrm{~cm}$ were -31.0 and $-59.1 \%$, ranging from -45.5 to $-19.8 \%$ and from -75.3 to $-48.7 \%$, respectively. The $d_{\text {soil }}$ values decreased with the increase in $T$ and the decrease in RH (Tables 2 and 4). Except at S3-Aug, there were no temporal trends in $d_{\text {soil }}$ at 5 and $10 \mathrm{~cm}$ (Fig. 5). The $d_{\text {soil }}$ values of 5 and $10 \mathrm{~cm}$ were lowest near 12:00. The highest observed $d_{\text {soil }}$ was from 02:00 to $06: 00$ for site S3-Aug during the first sunny day after the rainy day (Fig. 5d). 

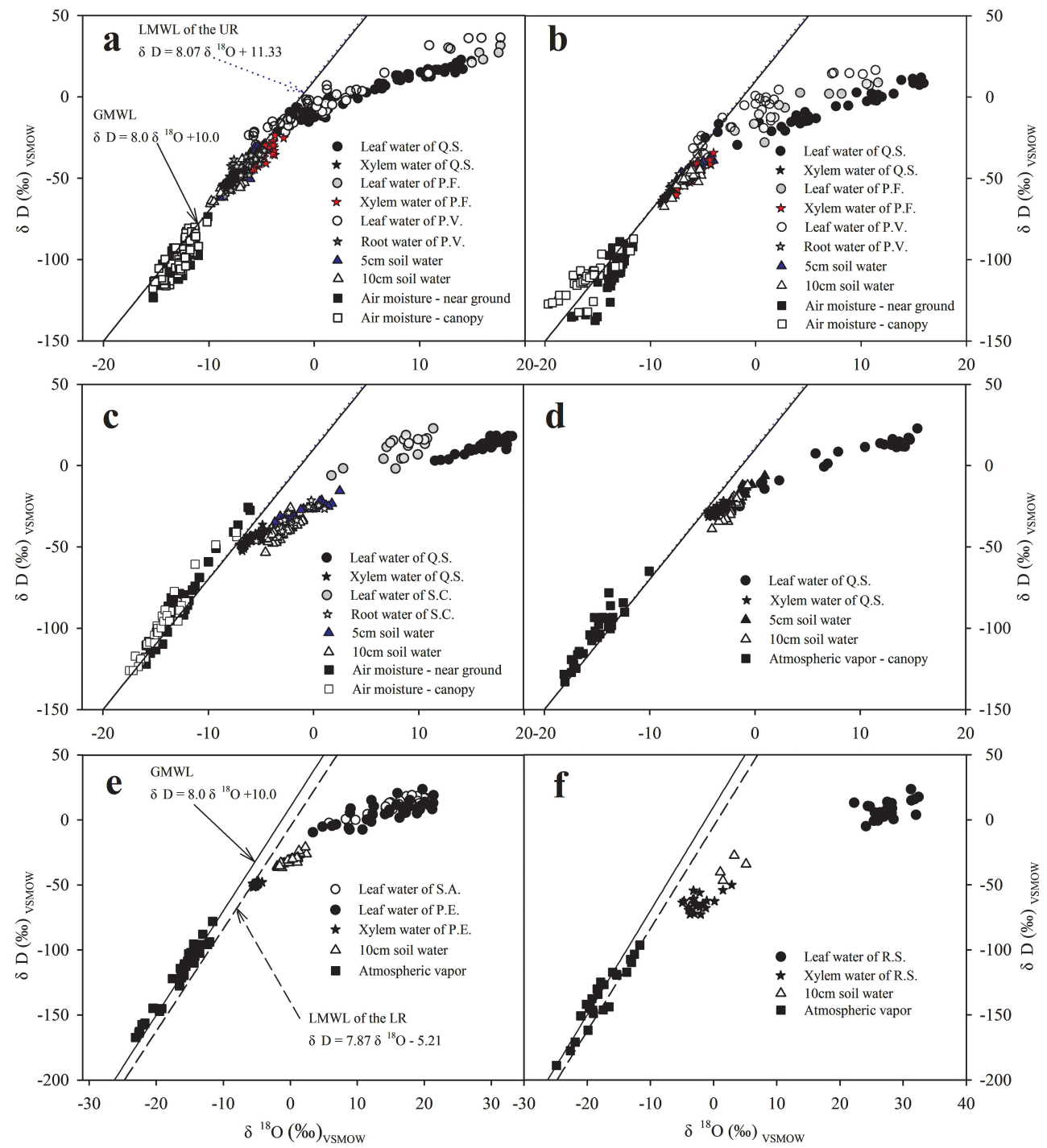

Figure 3. Plot of $\delta \mathrm{D}$ and $\delta^{18} \mathrm{O}$ of different water pools at each site. The LMWL (cited from He, 2011) is plotted for each site (the dark line is the GMWL (the global meteoric water line); the blue dotted line and the dashed lines are the LMWL of the upper and the lower reaches, respectively). Note: panels (a), (b), (c), (d), (e) and (f) refer to the same location as in Fig. 2, and the abbreviations of plant Latin names are the same as in Table 3.

Figure 6 shows the diurnal variations in air moisture dexcess $\left(d_{\text {moisture }}\right)$ from each study site on the sunny days. Although the patterns were similar at all sites, the peakto-trough amplitudes of $d_{\text {moisture }}$ varied greatly. They were $39.9 \%$ near the ground and $36.7 \%$ at the canopy in the upper reaches. In the lower reaches, the peak-to-trough amplitudes of $d_{\text {moisture }}$ at the canopy were $17.3 \%$ at S4-Aug and $30.6 \%$ at S5-Aug, respectively (Table 4 and Fig. 6). Ex-

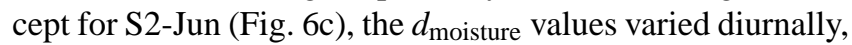
showing a clear and robust pattern of maximum $d_{\text {moisture }}$ during the mid-day (from about 10:00 to 16:00) (Fig. 6).

\subsubsection{Variations in d-excess in leaf water, xylem water, soil water and air moisture water during the cloudy days}

In our study, the cloudy days occurred only in the upper reaches (Table 1). The $d_{\text {leaf }}$ values during the cloudy days were significantly higher than those of the sunny days, and the $d_{\text {leaf }}$ values were significantly lower than the $d_{\text {xylem }}$ values (Table 5). During the cloudy days with low PAR in the upper reaches of the HRB, there were no clear diurnal variations for $d_{\text {moisture }}, d_{\text {leaf }}$ and $d_{\text {soil }}$ at 5 and $10 \mathrm{~cm}$ in depth, except for $d_{\text {moisture }}$ and $d_{\text {leaf }}$ at S1-Jun (Figs. 7 and 8). In addition, at S3-Aug, the $d_{\text {leaf }}$ increased gradually from 06:00 to 16:00 and showed the opposite diurnal variations compared 

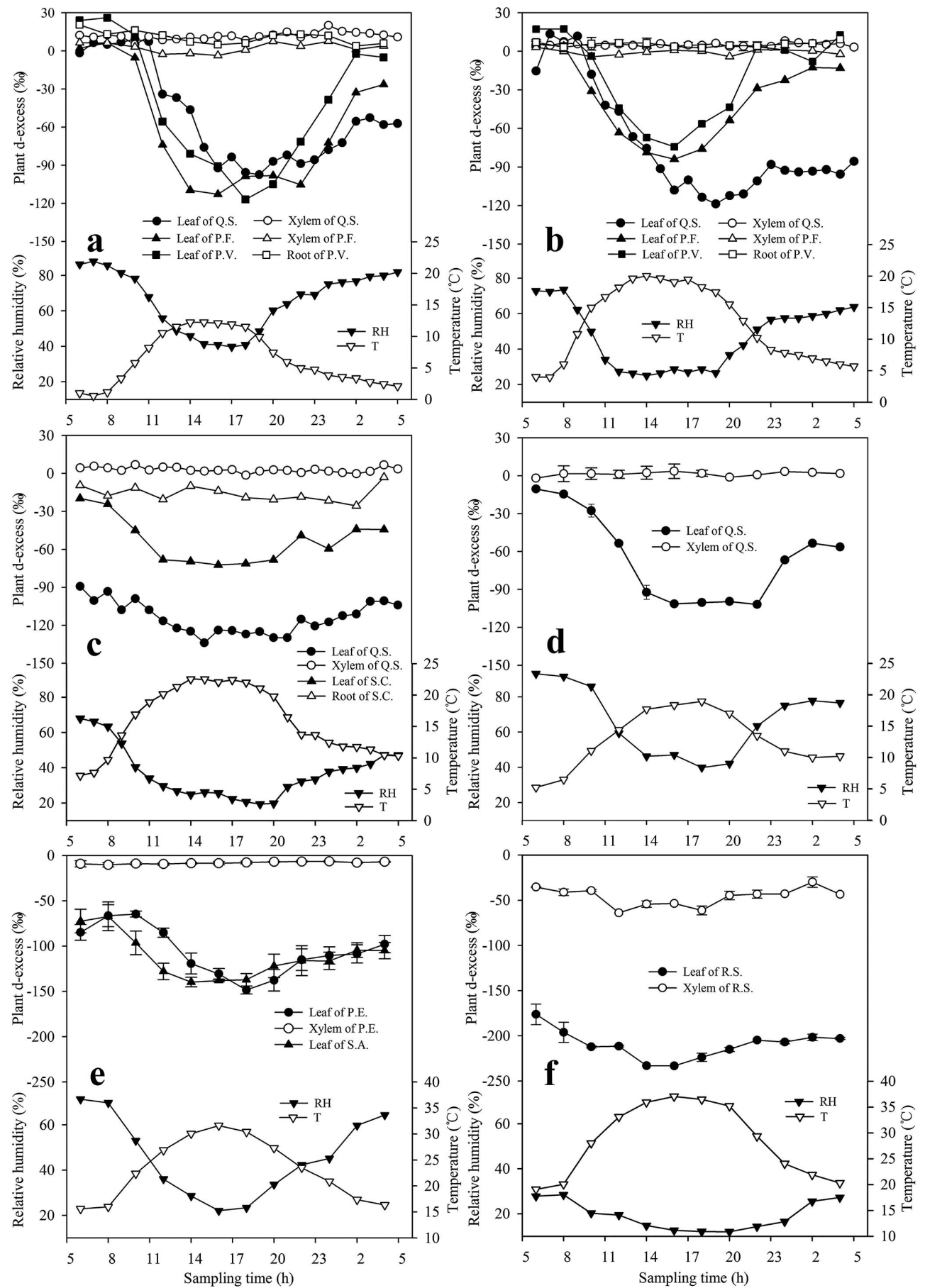

Figure 4. Variations in leaf and xylem water d-excess on the sunny days of the upper reaches and lower reaches of the Heihe River basin. Note: panels (a), (b), (c), (d), (e) and (f) refer to the same location as in Fig. 2, and the abbreviations of plant Latin names were the same as in Table 3. The following sunny days were selected: S1-Sep: from 06:00 to 18:00, 7 and 8 September; S1-Jun: from 06:00 to 16:00, 23 June; S2-Jun: from 06:00 to 16:00, 27 June; S3-Aug: from 06:00, 1 August to 16:00, 2 August and from 06:00 to 18:00, 3 August 2009. All data at S4-Aug and S5-Aug were selected. 

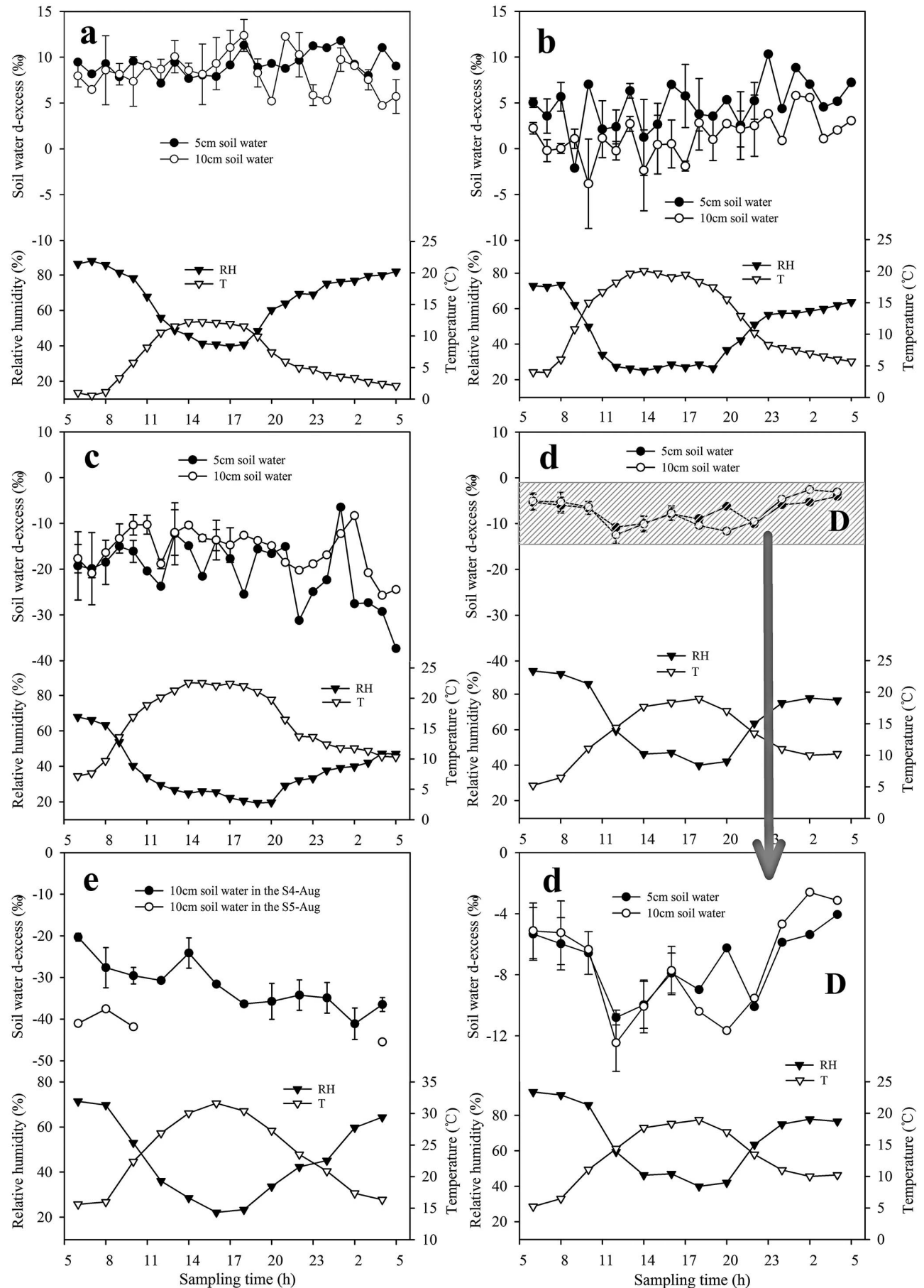

Figure 5. Spatial and temporal variations in soil water d-excess in the Heihe River basin. Note: panels (a), (b), (c), and (d) refer to the same locations as in Fig. 2, and panel (e) refers to S4-Aug and S5-Aug in the lower reaches. 

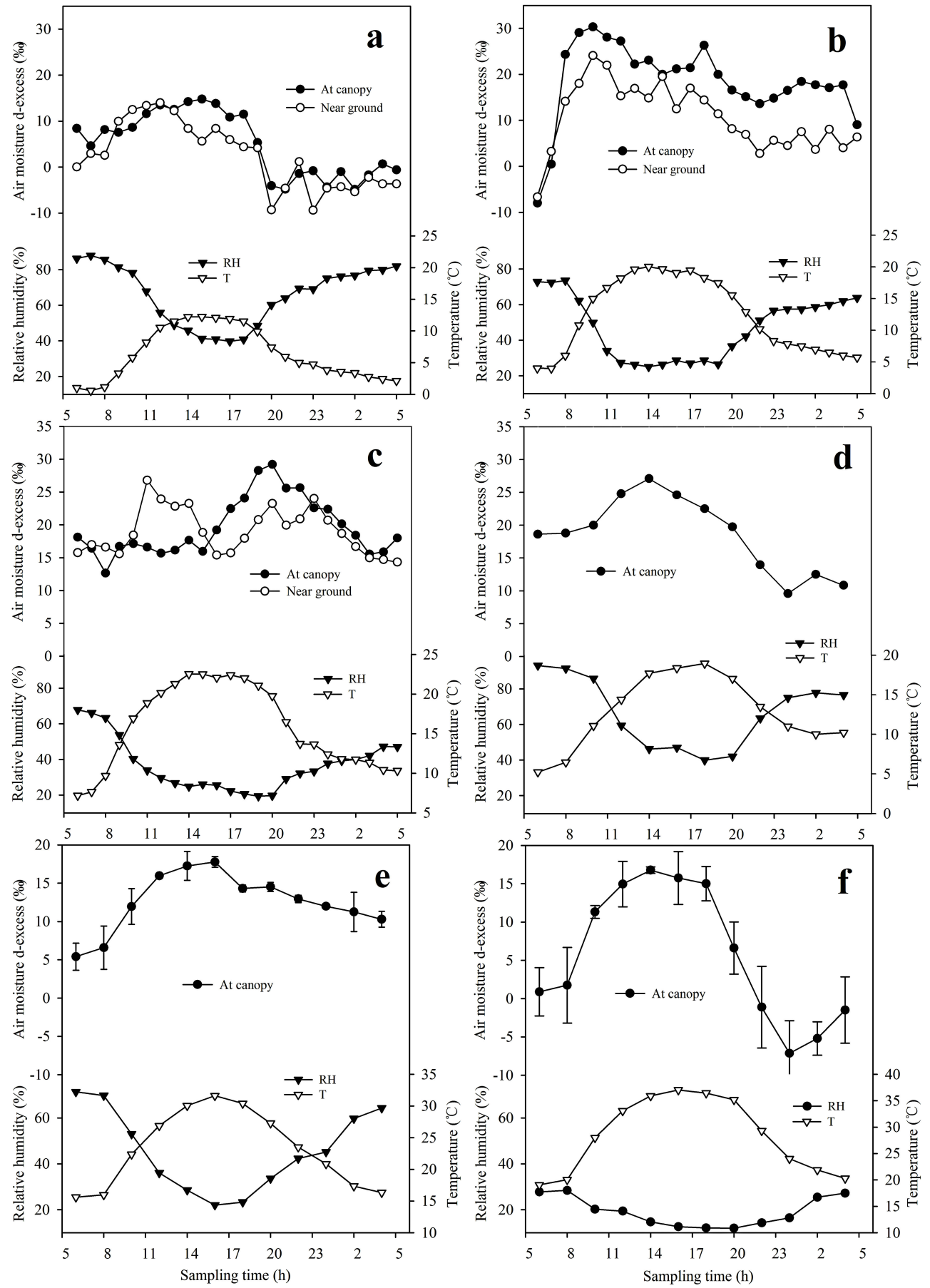

Figure 6. The d-excess of air moisture during the sunny days. Note: panels (a), (b), (c), (d), (e) and (f) refer to the same locations as in Fig. 2. 
Table 4. Spatial and temporal variations in the d-excess $(\%)$ of each water pool in the Heihe River basin. The numbers in parentheses indicate the number of samples. The location ID and the abbreviations of plant Latin names are the same as in Tables 2 and 3.

\begin{tabular}{|c|c|c|c|c|c|c|c|}
\hline \multirow{2}{*}{$\begin{array}{l}\text { Study sites } \\
\text { Plant species }\end{array}$} & \multicolumn{4}{|c|}{ S1-Sep, S1-Jun, S2-Jun and S3-Aug } & \multicolumn{2}{|c|}{ S4-Aug } & \multirow{2}{*}{$\begin{array}{r}\text { S5-Aug } \\
\text { R.S. }(n=23)\end{array}$} \\
\hline & Q.S. $(n=166)$ & P.F. $(n=51)$ & P.V. $(n=51)$ & S.C. $(n=23)$ & P.E. $(n=36)$ & S.A. $(n=36)$ & \\
\hline \multicolumn{5}{|c|}{ Leaf water } & \multicolumn{2}{|c|}{ Leaf water } & Leaf water \\
\hline Mean & -64.7 & -29.8 & -14.3 & -55.4 & -110.2 & -114.4 & -210.4 \\
\hline Minimum & -133.8 & -112.9 & -117.0 & -72.3 & -161.2 & -145.4 & -245.6 \\
\hline Maximum & 13.4 & 9.7 & 26.1 & -19.7 & -36.8 & -48.5 & -165.0 \\
\hline SD & 43.0 & 35.6 & 37.0 & 15.0 & 34.7 & 26.0 & 17.4 \\
\hline The peak-to-trough amplitudes & \multicolumn{4}{|c|}{ Xylem water } & \multicolumn{2}{|c|}{ Xylem water } & Xylem water \\
\hline Mean & 6.2 & 0.8 & 7.6 & -18.8 & -8.2 & - & -44.8 \\
\hline Minimum & -7.2 & -7.5 & 0.3 & -34.9 & -14.1 & - & -73.0 \\
\hline Maximum & 15.4 & 7.5 & 22.4 & -3.1 & -3.9 & - & -24.2 \\
\hline $\mathrm{SD}$ & 5.0 & 3.8 & 5.2 & 7.2 & 2.1 & - & 12.7 \\
\hline The peak-to-trough amplitudes & 22.6 & 15.0 & 22.1 & 31.8 & 10.2 & - & 48.8 \\
\hline Mean $d_{\text {xylem }}-d_{\text {leaf }}$ & 70.9 & 30.6 & 21.9 & 36.6 & 102.0 & - & 165.6 \\
\hline Soil water & \multicolumn{2}{|c|}{$5 \mathrm{~cm}$ soil water $(n=166)$} & \multicolumn{2}{|c|}{$10 \mathrm{~cm}$ soil water $(n=166)$} & \multicolumn{2}{|c|}{$10 \mathrm{~cm}$ soil water $(n=36)$} & $10 \mathrm{~cm}$ soil water $(n=4)$ \\
\hline Mean & \multicolumn{2}{|c|}{-0.9} & \multicolumn{2}{|c|}{-1.2} & \multicolumn{2}{|c|}{-31.0} & -59.1 \\
\hline Minimum & \multicolumn{2}{|c|}{-37.3} & \multicolumn{2}{|c|}{-25.7} & \multicolumn{2}{|c|}{-45.5} & -75.3 \\
\hline Maximum & \multicolumn{2}{|c|}{14.3} & \multicolumn{2}{|c|}{16.6} & \multicolumn{2}{|c|}{-19.8} & -48.7 \\
\hline SD & \multicolumn{2}{|c|}{12.5} & \multicolumn{2}{|c|}{10.0} & \multicolumn{2}{|c|}{6.2} & 11.5 \\
\hline The peak-to-trough amplitudes & \multicolumn{2}{|c|}{51.6} & \multicolumn{2}{|c|}{42.3} & \multicolumn{2}{|c|}{25.7} & 26.6 \\
\hline Air moisture & \multicolumn{2}{|c|}{ At the canopy $(n=172)$} & \multicolumn{2}{|c|}{ Near the ground $(n=172)$} & \multicolumn{2}{|c|}{ At the canopy $(n=36)$} & At the canopy $(n=23)$ \\
\hline Mean & \multicolumn{2}{|c|}{7.7} & & & 12 & & 5.6 \\
\hline Minimum & -9 & & & & 2 & & -11.4 \\
\hline Maximum & 26.8 & & & & 19 & & 19.2 \\
\hline $\mathrm{SD}$ & 8.5 & & & & 4 & & 9.1 \\
\hline The peak-to-trough amplitudes & 36. & & & & 17 & & 30.6 \\
\hline Mean $d_{\text {moisture }}-d_{\text {soil }}$ & 8.6 & & & & 43 & & 64.7 \\
\hline
\end{tabular}

Table 5. Differences between $d_{x y l e m}(\% o)$ and $d_{\text {leaf }}(\%)$ on the sunny and the cloudy days. The location ID and the abbreviations of plant Latin names are the same as in Tables 2 and 3.

\begin{tabular}{|c|c|c|c|c|c|c|c|c|c|}
\hline \multirow[t]{2}{*}{$\begin{array}{l}\text { Study } \\
\text { sites }\end{array}$} & \multirow[t]{2}{*}{$\begin{array}{r}\text { Plant } \\
\text { species }\end{array}$} & \multicolumn{3}{|c|}{ The sunny day } & \multicolumn{3}{|c|}{ The cloudy day } & \multirow{2}{*}{$\begin{array}{r}\begin{array}{r}\text { Difference } \\
\text { in } d_{\text {leaf }}\end{array} \\
d_{\text {cloudy }}-d_{\text {sunny }}\end{array}$} & \multirow{2}{*}{$\begin{array}{r}\begin{array}{r}\text { Difference } \\
\text { in } d_{\text {xylem }}\end{array} \\
d_{\text {cloudy }}-d_{\text {sunny }}\end{array}$} \\
\hline & & $d_{\text {leaf }}$ & $d_{\text {xylem }}$ & $d_{\text {xylem }}-d_{\text {leaf }}$ & $d_{\text {leaf }}$ & $d_{\text {xylem }}$ & $d_{\text {xylem }}-d_{\text {leaf }}$ & & \\
\hline \multirow{3}{*}{ S1-Sep } & Q.S. & -51.9 & 11.8 & 63.7 & -6.8 & 12.0 & 18.8 & 45.1 & 0.1 \\
\hline & P.F. & -60.6 & 2.7 & 63.3 & -4.9 & 2.7 & 7.6 & 55.7 & 0.0 \\
\hline & P.V. & -42.0 & 10.6 & 52.7 & 11.1 & 8.3 & -2.8 & 53.2 & -2.3 \\
\hline \multirow[t]{3}{*}{ S1-Jun } & Q.S. & -72.0 & 5.0 & 77.1 & -47.4 & 5.2 & 52.6 & 24.7 & 0.2 \\
\hline & P.F. & -37.8 & -0.6 & 37.2 & -15.5 & -1.1 & 14.4 & 22.3 & -0.5 \\
\hline & P.V. & -20.4 & 5.5 & 25.9 & -4.6 & 6.4 & 11.0 & 15.9 & 1.0 \\
\hline \multirow[t]{2}{*}{ S2-Jun } & Q.S. & -114.0 & 2.9 & 116.9 & -116.9 & -0.2 & 116.7 & -2.9 & -3.1 \\
\hline & S.C. & -52.9 & -15.9 & 37.0 & -59.5 & -23.7 & 35.8 & -6.6 & -7.8 \\
\hline S3-Aug & Q.S. & -64.9 & 1.4 & 66.3 & -52.8 & 4.0 & 56.8 & 12.0 & 2.5 \\
\hline \multicolumn{2}{|c|}{ Mean } & -57.4 & 2.6 & 60.0 & -33.0 & 1.5 & 34.5 & 24.4 & -1.1 \\
\hline
\end{tabular}

to those of the sunny days. The likely reason is the leaf absorption of precipitation with high d-excess (e.g., $11.8 \%$ as in Zhao et al., 2011b) during the rainy conditions (precipitation occurred from 10:40 to 22:00 on 2 August).

During the sunny days, a large difference between $d_{\text {xylem }}$ and $d_{\text {leaf }}$ was found, and the $d_{\text {xylem }}-d_{\text {leaf }}$ values varied from
25.9 to $116.9 \%$, with a mean value of $60.0 \%$. Except at S2-Jun, the mean difference between $d_{\text {xylem }}$ and $d_{\text {leaf }}$ during the cloudy days was $22.6 \%$, and this value was lower than that of the sunny days. A large difference in $d_{\text {leaf }}$ between the sunny and cloudy days was found, with a mean of $32.7 \%$ o (excluding S2-Jun), and the difference varied from 12.0 to 
$55.7 \%$ (excluding S2-Jun). There was no obvious difference in $d_{\text {xylem }}$ between the sunny and cloudy days, except at S2Jun (Table 5).

\subsection{Controlling factors of the d-excess in different water pools}

\subsubsection{Relationships between the d-excess of various pools and RH}

Significantly positive correlations were found between $d_{\text {leaf }}$ and $\mathrm{RH}$ at all the study sites during the entire study periods (from June to September) (Table 6). Significantly positive correlations were also found between $d_{\text {leaf }}$ and $\mathrm{RH}$ at all the study sites during the sunny days (Table 7). As RH increased by $1 \%$, the increasing magnitude of $d_{\text {leaf }}$ ranged from 0.49 to $2.53 \%$ in the upper reaches. In the lower reaches, as $\mathrm{RH}$ increased by $1 \%$, the increasing magnitude of $d_{\text {leaf }}$ ranged from 1.21 to $1.77 \%$ o (Table 6).

Except for near the ground at S1-Sep, significantly negative correlations were found between $d_{\text {moisture }}$ and $\mathrm{RH}$ at all the study sites when including both the sunny and cloudy days (Table 6). A significantly negative correlation was found between $d_{\text {moisture }}$ and RH at S1-Sep when only the sunny days were considered (Table 7). The $d_{\text {moisture }} / \mathrm{RH}$ values were $-0.15 \% \%^{-1}$ at S1-Jun and $-0.27 \% \%^{-1}$ at S2-Jun for near-ground air moisture. For the canopy air moisture, the $d_{\text {moisture }} / \mathrm{RH}$ values were $-0.24,-0.32,-0.25,-0.15$, -0.13 and $-0.68 \% \%^{-1}$ at S1-Sep, S1-Jun, S2-Jun, S3Aug, S4-Aug and S5-Aug, respectively. During the sunny days, the $d_{\text {moisture }} / \mathrm{RH}$ values were -0.36 and $-0.31 \% \%^{-1}$, respectively, for near the ground and at the canopy in the upper reaches, which were larger than the results based on data including both the sunny and cloudy days (Table 7). In terms of $d_{\text {soil }}$, the correlations between the $d_{\text {soil }}$ of $10 \mathrm{~cm}$ at S1-Sep, S3-Aug and RH, and between the $d_{\text {soil }}$ of $5 \mathrm{~cm}$ at S1-Jun and $\mathrm{RH}$, were significant (Table 6).

\subsubsection{Relationships between the d-excess of various pools and $T$}

Significantly negative relationships were found between $d_{\text {leaf }}$ and $T$ in both the upper reaches and the lower reaches, except in Q.S. at S1-Jun (Table 8). The decreasing magnitudes of $d_{\text {leaf }}$ with $T$ in Q.S. were $-3.27,-1.59$ and $-6.25 \% 0^{\circ} \mathrm{C}^{-1}$ at S1-Sep, S2-Jun and S3-Aug, respectively. The magnitudes were -6.45 and $-5.10 \% 0^{\circ} \mathrm{C}^{-1}$ for P.F., and -6.74 and $-5.07 \% 0^{\circ} \mathrm{C}^{-1}$ for P.V. for S1-Sep and S1-Jun, respectively. The magnitude was $-2.21 \%{ }^{\circ} \mathrm{C}^{-1}$ in S.C. at S2-Jun. During the sunny days, there were significantly negative relationships between $d_{\text {leaf }}$ and $T$ in both the upper and lower reaches (Tables 7 and 8). In the lower reaches, the decreasing magnitudes of $d_{\text {leaf }}$ in P.E. and S.A. were -4.40 and $-2.15 \% 0^{\circ} \mathrm{C}^{-1}$, respectively, at $\mathrm{S} 4$-Aug. It was $-1.82 \%{ }^{\circ} \mathrm{C}^{-1}$ for R.S. at S5-Aug (Table 8).
There were significantly positive relationships between $d_{\text {moisture }}$ and $T$ at all sites except S2-Jun (Table 8). The $d_{\text {moisture }} / T$ values near the ground were 0.54 and $0.76 \%{ }^{\circ} \mathrm{C}^{-1}$ at S1-Sep and S1-Jun, respectively. The $d_{\text {moisture }} / T$ values at the canopy were $0.81,0.91,0.64,0.54$ and $0.83 \%{ }^{\circ} \mathrm{C}^{-1}$ at S1-Sep, S1-Jun, S3-Aug, S4-Aug and S5-Aug, respectively (Table 8). During the sunny days, the $d_{\text {moisture }} / T$ values were 1.18 and $1.11 \%{ }^{\circ} \mathrm{C}^{-1}$, respectively, for near the ground and at the canopy, which were larger than the results based on data including both the sunny and cloudy days (Table 7).

At S2-Jun, there were positive relationships between $d_{\text {soil }}$ (both 5 and $10 \mathrm{~cm}$ in depth) and $T$, and the $d_{\text {soil }} / T$ values were $0.88 \% 0^{\circ} \mathrm{C}^{-1}(p=0.021)$ and $0.34 \%{ }^{\circ} \mathrm{C}^{-1}(p=$ $0.045)$ for 5 and $10 \mathrm{~cm}$ in depth, respectively. However, at S3-Aug, there were negative relationships between $d_{\text {soil }}$ (both 5 and $10 \mathrm{~cm}$ in depth) and $T$, and the $d_{\text {soil }} / T$ values were $-0.45 \%{ }^{\circ} \mathrm{C}^{-1}(p=0.009)$ and $-0.54 \% 0^{\circ} \mathrm{C}^{-1}(p=0.002)$ for 5 and $10 \mathrm{~cm}$ in depth, respectively. A significantly negative relationship was also found between the $d_{\text {soil }}$ of $5 \mathrm{~cm}$ in depth and $T$ at $\operatorname{S} 1-\operatorname{Sep}\left(d_{\text {soil }} / T=-0.16 \% 0^{\circ} \mathrm{C}^{-1}, p=0.002\right)$ (Table 8).

\subsubsection{Relationships between the d-excess of various pools}

During the sunny days, we found an opposite pattern between the diurnal variations in $d_{\text {leaf }}$ and $d_{\text {moisture }}$ (Fig. 9). A similar pattern was found between $d_{\text {soil }}$ and $d_{\text {moisture during the }}$ first sunny day after the rain. The $d_{\text {leaf }}\left(d_{\text {soil }}\right)$ became more negative, while $d_{\text {moisture }}$ became more positive during the afternoon, and opposite patterns were found during the night (Figs. 9 and 10). There were significantly negative relationships between $d_{\text {leaf }}$ and $d_{\text {moisture }}$ at three study sites (Table 7). In the upper reaches, $d_{\text {leaf }}$ of wood species (Q.S.) were correlated significantly with $d_{\text {moisture }}$ both near the ground and at the canopy, and the slopes were -1.47 and -1.40 , respectively. Significantly negative relationships were also found between $d_{\text {leaf }}$ of shrub/grass and $d_{\text {moisture }}$ near the ground, and the slopes were -0.14 and -0.12 , respectively. In the lower reaches, the slopes of $d_{\text {leaf }}$ and $d_{\text {moisture }}$ at the canopy were -0.06 in woody species (P.E.), and -0.10 and -0.28 in shrub (S.A.), at S4-Aug and S5-Aug, respectively (Table 7).

\subsection{Modeling results of leaf water $\delta^{18} O, \delta \mathrm{D}$ and d-excess}

The steady-state Craig-Gordon model captured the diurnal variations in $\delta^{18} \mathrm{O}, \delta \mathrm{D}$ and d-excess, but a discrepancy existed between modeled and observed values (Fig. 11). During the day, the observed values of $\delta^{18} \mathrm{O}$ and $\delta \mathrm{D}$ were lower, while d-excess values were higher than those predicted by the steady-state Craig-Gordon model. At night, the observed values of $\delta^{18} \mathrm{O}$ and $\delta \mathrm{D}$ were higher, while d-excess values were slightly lower than those predicted by the model. On 

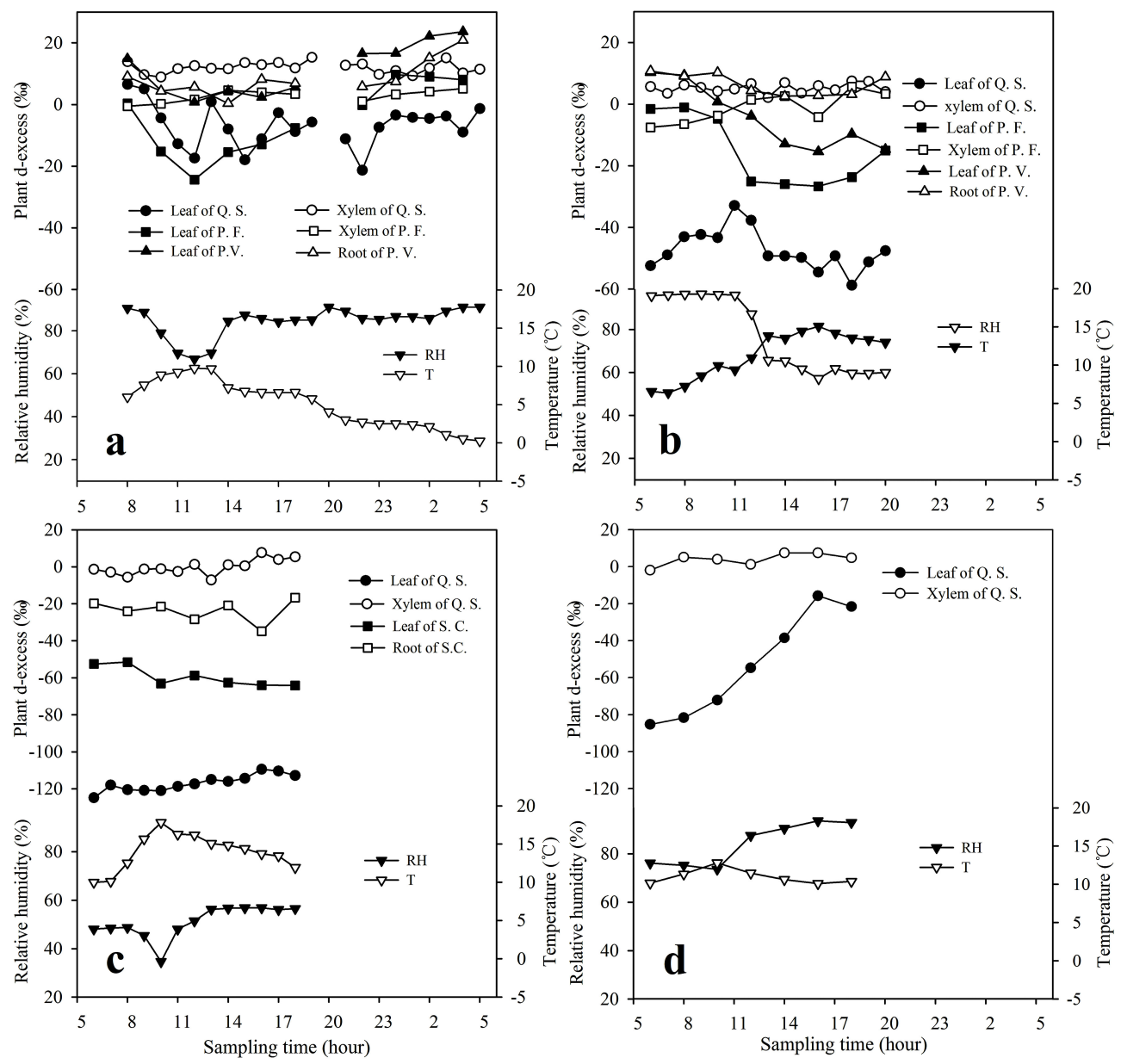

Figure 7. Variations in leaf and xylem water d-excess of the upper reaches of the Heihe River basin during the cloudy days. Note: panels (a), (b), (c) and (d) refer to the same location as in Fig. 2, and the abbreviations of plant Latin names were the same as in Table 3.

average, the modeled leaf water $\delta^{18} \mathrm{O}$ and $\delta \mathrm{D}$ values were 1.8 and $6.7 \%$ o higher, while d-excess values were $7.5 \%$ lower than those of observed values. The steady-state predictions explained $79.5 \%$ of variations in modeled $\delta^{18} \mathrm{O}$, and 63.4 and $64.2 \%$ of variations in modeled $\delta \mathrm{D}$ and d-excess (Fig. 11).

\section{Discussion}

\subsection{Variations in $\delta \mathrm{D}$ and $\delta^{18} \mathrm{O}$ in different water pools}

Our results show that there are significant differences in the $\delta \mathrm{D}$ and $\delta^{18} \mathrm{O}$ of leaf water, xylem water, soil water and air moisture, and different $\delta \mathrm{D}-\delta^{18} \mathrm{O}$ patterns due to hydrogen and oxygen isotopic discrimination related to soil evaporation, plant transpiration and plant physiology. For example, compared to those of xylem water and shallow soil water, leaf water has the highest average $\delta \mathrm{D}$ and $\delta^{18} \mathrm{O}$ values and the largest ranges at all the study sites. In addition, the $\delta \mathrm{D}-$ $\delta^{18} \mathrm{O}$ regression lines of leaf water highly deviate from their corresponding LMWL (Table 2 and Fig. 3), suggesting a strong transpiration enrichment effect. With the decrease in $\mathrm{RH}$ and the increase in $T$, leaf water $\delta \mathrm{D}$ and $\delta^{18} \mathrm{O}$ values increased, and the $\delta \mathrm{D}-\delta^{18} \mathrm{O}$ regression lines gradually deviate from their corresponding LMWL due to stronger transpiration, suggesting that climatic conditions have a significant effect on variations in leaf water $\delta \mathrm{D}$ and $\delta^{18} \mathrm{O}$ and their correlations by affecting transpiration (Tables 2 and 3).

In the upper reaches, at high-altitude sites such as S1-Sep and S1-Jun, the patterns of $\delta \mathrm{D}-\delta^{18} \mathrm{O}$ regression lines in shallow soil water and xylem water are similar (Fig. 3a and b), suggesting that the water sources of plants are from shallow soil water, and soil waters are subject to only mild evaporation. These results are consistent with the fact of the horizontal distributions of Q.S. roots and the shallow rooting of herbaceous plants such as P.V. However, at relatively lower altitudes such as at S2-Jun and S3-Aug, the xylem water $\delta \mathrm{D}$ and $\delta^{18} \mathrm{O}$ of Q.S. are lower than those of soil water, except for the herbaceous plant (S.C.) (Table 3), and the $\delta \mathrm{D}-\delta^{18} \mathrm{O}$ regression lines of soil water deviate from the LMWL (Fig. 3). 

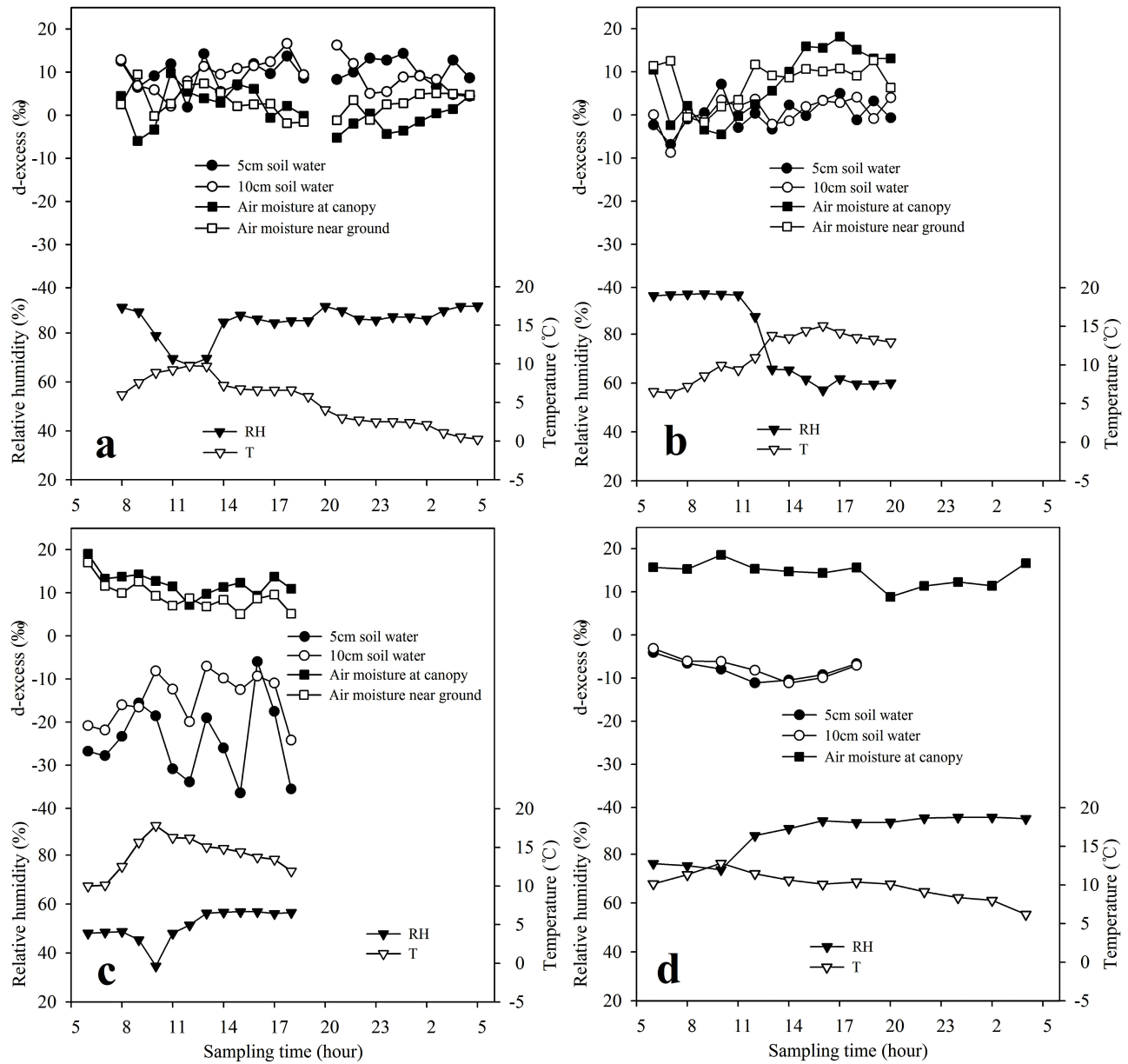

Figure 8. Variations in d-excess of shallow soil water and air moisture during the cloudy days of the upper reaches of the Heihe River basin. Note: panels (a), (b), (c) and (d) refer to the same locations as in Fig. 2.

These results may be related to stronger soil evaporation in shallow soil layers. In the lower reaches, the $\delta \mathrm{D}$ and $\delta^{18} \mathrm{O}$ of $10 \mathrm{~cm}$ soil water are significantly higher than those of P.E. and R.S. xylem water, and the $\delta \mathrm{D}-\delta^{18} \mathrm{O}$ regression lines obviously deviate from the LMWL of the lower reaches, suggesting that strong soil water evaporation occurs in shallow soil in the lower reaches.

As expected, the isotopic results show that the soil water at 5 and $10 \mathrm{~cm}$ is affected by evaporation, which is indicated by a slope of less than 8.0 (Dansgaard, 1964). In our study, the slopes of 5 and $10 \mathrm{~cm}$ of the soil water evaporation line vary from 2.6 to 7.4 (Table 9). Relative high slopes were found at S1-Sep (7.1) and S3-Aug (7.4), likely due to low temperatures during September at S1-Sep and the rain event at S3Aug. The slopes of other sites are lower than 5.0, especially in the lower reaches, and the values in the slopes are very small at S4-Aug (2.6) and S5-Aug (2.8) (Table 9), revealing strong shallow water evaporation. These slope values are comparable with other studies in vadose zones with evaporation slopes between 2 and 5 (Allison, 1982; Clark and Fritz,
1997; Kendall and McDonnell, 1999; Wenninger et al., 2010; Sutanto et al., 2012). The patterns of the $\delta \mathrm{D}-\delta^{18} \mathrm{O}$ regression lines from shallow soil water gradually deviate from their corresponding LMWL with the decrease in altitude, suggesting stronger water loss through direct evaporation, especially in extremely arid regions such as the riparian forest site and the Gobi site in the lower reaches of the HRB.

The air moisture has the most depleted $\delta \mathrm{D}$ and $\delta^{18} \mathrm{O}$ compared to leaf water, xylem water and shallow soil water (Table 3). The air moisture $\delta \mathrm{D}$ and $\delta^{18} \mathrm{O}$ data cluster around the corresponding LMWL (Fig. 3). These results are consistent with the isotopic fractionation theory (Gat, 1996), and they are also consistent with a previous study in urban settings, agricultural settings, forest and grassland in China, Canada and the USA (Welp et al., 2012). 
Table 6. Linear least square fits between the d-excess of various water bodies and the relative humidity (RH) $(\%)$ at each site. Here, $r$ is the correlation coefficient, and $p$ is the significance level. $p<0.001$ indicates statistical significance at the $99.9 \%$ significance level, and $p<0.05$ indicates statistical significance at the $95 \%$ significance level. The location ID and the abbreviations of plant Latin names are the same as in Tables 2 and 3.

\begin{tabular}{|c|c|c|c|c|c|c|c|c|c|}
\hline \multicolumn{10}{|c|}{ d-excess (\%o) vs. RH (\%) } \\
\hline & Slope & Intercept & $r$ & $p$ & & Slope & Intercept & $r$ & $p$ \\
\hline \multicolumn{5}{|c|}{ S1-Sep } & \multicolumn{5}{|c|}{ S1-Jun } \\
\hline$d_{\text {leaf }}$ of Q.S. & 1.52 & -146.68 & 0.701 & $<0.001$ & $d_{\text {leaf }}$ of Q.S. & 0.82 & -113.36 & 0.589 & $<\mathbf{0 . 0 0 1}$ \\
\hline$d_{\text {leaf }}$ of P.F. & 2.38 & -212.45 & 0.846 & $<\mathbf{0 . 0 0 1}$ & $d_{\text {leaf }}$ of P.F. & 1.07 & -90.47 & 0.825 & $<0.001$ \\
\hline$d_{\text {leaf }}$ of P.V. & 2.53 & -208.14 & 0.879 & $<\mathbf{0 . 0 0 1}$ & $d_{\text {leaf }}$ of P.V. & 0.99 & -72.05 & 0.723 & $<\mathbf{0 . 0 0 1}$ \\
\hline$d_{\text {soil }}$ of $5 \mathrm{~cm}$ & 0.03 & 6.61 & 0.198 & 0.122 & $d_{\text {soil }}$ of $5 \mathrm{~cm}$ & -0.10 & 9.42 & -0.483 & 0.001 \\
\hline$d_{\text {soil }}$ of $10 \mathrm{~cm}$ & 0.08 & 1.84 & 0.253 & 0.048 & $d_{\text {soil }}$ of $10 \mathrm{~cm}$ & $<0.01$ & 1.10 & -0.046 & 0.775 \\
\hline$d_{\text {moisture }}$ near the ground & -0.11 & 9.62 & -0.168 & 0.191 & $d_{\text {moisture }}$ near the ground & -0.15 & 18.50 & -0.477 & 0.001 \\
\hline$d_{\text {moisture }}$ at the canopy & -0.24 & 20.56 & -0.457 & $<0.001$ & $d_{\text {moisture }}$ at the canopy & -0.32 & 33.83 & -0.753 & $<\mathbf{0 . 0 0 1}$ \\
\hline \multicolumn{5}{|c|}{ S2-Jun } & \multicolumn{5}{|c|}{ S3-Aug } \\
\hline$d_{\text {leaf }}$ of Q.S. & 0.49 & -135.82 & 0.686 & $<0.001$ & $d_{\text {leaf }}$ of Q.S. & 1.48 & -169.36 & 0.716 & $<0.001$ \\
\hline$d_{\text {leaf }}$ of S.C. & 0.56 & -79.08 & 0.523 & 0.022 & & & & & \\
\hline$d_{\text {soil }}$ of $5 \mathrm{~cm}$ & -0.21 & -10.54 & -0.279 & 0.094 & $d_{\text {soil }}$ of $5 \mathrm{~cm}$ & 0.05 & -9.86 & 0.289 & 0.161 \\
\hline$d_{\text {soil }}$ of $10 \mathrm{~cm}$ & -0.02 & -14.72 & 0.013 & 0.941 & $d_{\text {soil }}$ of $10 \mathrm{~cm}$ & 0.08 & -12.35 & 0.403 & 0.046 \\
\hline$d_{\text {moisture }}$ near the ground & -0.27 & 26.82 & -0.682 & $<0.001$ & & & & & \\
\hline$d_{\text {moisture }}$ at the canopy & -0.25 & 27.58 & -0.689 & $<0.001$ & $d_{\text {moisture }}$ at the canopy & -0.15 & 28.37 & -0.526 & 0.007 \\
\hline \multicolumn{5}{|c|}{ S4-Aug } & \multicolumn{5}{|c|}{ S5-Aug } \\
\hline$d_{\text {leaf }}$ of P.E. & 1.41 & -171.76 & 0.844 & $<\mathbf{0 . 0 0 1}$ & $d_{\text {leaf }}$ of R.S. & 1.77 & -243.96 & 0.716 & $<\mathbf{0 . 0 0 1}$ \\
\hline$d_{\text {leaf }}$ of S.A. & 1.21 & -166.99 & 0.947 & $<0.001$ & & & & & \\
\hline$d_{\text {soil }}$ of $10 \mathrm{~cm}$ & 0.02 & -32.08 & -0.012 & 0.939 & & & & & \\
\hline$d_{\text {moisture }}$ at the canopy & -0.13 & 17.42 & -0.602 & 0.003 & $d_{\text {moisture }}$ at the canopy & -0.68 & 18.47 & -0.526 & $<0.001$ \\
\hline
\end{tabular}

Table 7. Correlations between the d-excess of various water bodies and $\mathrm{RH}(\%)$ and $T\left({ }^{\circ} \mathrm{C}\right)$, and between $d_{\text {moisture }}$ and $d_{\text {leaf }}$ during the sunny days at each site. Here, $r$ is the correlation coefficient, and $p$ is the significance level. $p<0.001$ indicates statistical significance at the $99.9 \%$ significance level, and $p<0.05$ indicates statistical significance at the $95 \%$ significance level. The location ID and the abbreviations of plant Latin names are the same as in Tables 2 and 3. The periods of the sunny days are the same as in Fig. 5.

\begin{tabular}{|c|c|c|c|c|c|c|c|c|c|}
\hline \multirow[t]{2}{*}{ Study area } & & \multicolumn{4}{|c|}{ The d-excess values vs. RH (\%) } & \multicolumn{4}{|c|}{ The d-excess values vs. $T\left({ }^{\circ} \mathrm{C}\right)$} \\
\hline & & Slope & Intercept & $r$ & $p$ & Slope & Intercept & $r$ & $p$ \\
\hline & $d_{\text {moisture }}$ near the ground & -0.36 & 27.643 & $-0.712(84)$ & $<0.001$ & 1.18 & -4.574 & 0.771 & $<0.001$ \\
\hline & $d_{\text {moisture }}$ at the canopy & -0.31 & 28.269 & $-0.617(101)$ & $<0.001$ & 1.11 & 0.695 & 0.716 & $<0.001$ \\
\hline & $d_{\text {leaf }}$ of wood & 1.26 & -131.626 & $0.600(102)$ & $<0.001$ & -3.84 & -19.327 & 0.630 & $<0.001$ \\
\hline S1-Sep & $d_{\text {leaf }}$ of shrub & 1.26 & -121.121 & $0.629(25)$ & $<0.001$ & -3.66 & -15.489 & 0.547 & $<0.001$ \\
\hline S1-Jun & $d_{\text {leaf }}$ of herb & 1.21 & -99.962 & $0.635(37)$ & $<0.001$ & -3.17 & -1.134 & 0.563 & $<0.001$ \\
\hline \multirow{4}{*}{$\begin{array}{l}\text { S2-Jun } \\
\text { S3-Aug }\end{array}$} & $d_{\text {leaf }}$ of wood vs. $d_{\text {moisture }}$ near the ground & -1.47 & -63.237 & $-0.360(84)$ & $<0.001$ & - & - & - & - \\
\hline & $d_{\text {leaf }}$ of wood vs. $d_{\text {moisture }}$ at the canopy & -1.40 & -52.568 & $-0.340(101)$ & $<0.001$ & - & - & - & - \\
\hline & $d_{\text {leaf }}$ of shrub vs. $d_{\text {moisture }}$ near the ground & -0.14 & 3.69 & $-0.599(24)$ & 0.039 & - & - & - & - \\
\hline & $d_{\text {leaf }}$ of grass vs. $d_{\text {moisture }}$ near the ground & -0.12 & 12.72 & $-0.648(12)$ & 0.023 & - & - & - & - \\
\hline \multirow[t]{2}{*}{ S4-Aug } & $d_{\text {leaf }}$ of wood vs. $d_{\text {moisture }}$ at the canopy & -0.06 & 7.163 & $-0.543(32)$ & $<0.001$ & - & - & - & - \\
\hline & $d_{\text {leaf }}$ of shrub vs. $d_{\text {moisture }}$ at the canopy & -0.10 & 1.827 & $-0.534(32)$ & $<0.001$ & - & - & - & - \\
\hline S5-Aug & $d_{\text {leaf }}$ of shrub vs. $d_{\text {moisture }}$ at the canopy & -0.28 & -57.737 & $0.540(25)$ & $<0.001$ & - & - & - & - \\
\hline
\end{tabular}


Table 8. Linear least square fits between the d-excess of various water bodies and the temperature $(T)\left({ }^{\circ} \mathrm{C}\right)$ at each site. Here, $r$ is the correlation coefficient, and $p$ is the significance level. $p<0.001$ indicates statistical significance at the $99.9 \%$ significance level, and $p<0.05$ indicates statistical significance at the $95 \%$ significance level. The location ID and the abbreviations of plant Latin names are the same as in Tables 2 and 3 .

\begin{tabular}{|c|c|c|c|c|c|c|c|c|c|}
\hline \multicolumn{10}{|c|}{ d-excess $(\% o)$ vs. $T\left({ }^{\circ} \mathrm{C}\right)$} \\
\hline & Slope & Intercept & $r$ & $p$ & & Slope & Intercept & $r$ & $p$ \\
\hline \multicolumn{5}{|c|}{ S1-Sep } & \multicolumn{5}{|c|}{ S1-Jun } \\
\hline Q.S. leaf water & -3.27 & -13.20 & -0.419 & $<0.001$ & Q.S. leaf water & -1.60 & -46.89 & -0.202 & 0.220 \\
\hline P.F. leaf water & -6.45 & 5.88 & -0.612 & $<0.001$ & P.F. leaf water & $-\mathbf{5 . 1 0}$ & 31.80 & -0.919 & $<0.001$ \\
\hline P.V. leaf water & -6.74 & 22.91 & -0.575 & $<0.001$ & P.V. leaf water & -5.07 & 45.80 & -0.942 & $<0.001$ \\
\hline $5 \mathrm{~cm}$ soil water & -0.16 & 10.17 & -0.387 & 0.002 & $5 \mathrm{~cm}$ soil water & 0.12 & 2.36 & 0.075 & 0.635 \\
\hline $10 \mathrm{~cm}$ soil water & 0.06 & 7.62 & 0.143 & 0.268 & $10 \mathrm{~cm}$ soil water & -0.09 & 2.15 & -0.087 & 0.585 \\
\hline Air moisture near the ground & 0.54 & -1.78 & 0.349 & 0.005 & Air moisture near the ground & 0.76 & 0.86 & 0.610 & $<0.001$ \\
\hline Air moisture at the canopy & 0.81 & -2.63 & 0.481 & $<0.001$ & Air moisture at the canopy & 0.91 & 4.12 & 0.494 & 0.003 \\
\hline \multicolumn{5}{|c|}{ S2-Jun } & \multicolumn{5}{|c|}{ S3-Aug } \\
\hline Q.S. leaf water (37) & -1.59 & -90.88 & -0.664 & $<\mathbf{0 . 0 0 1}$ & Q.S. leaf water & -6.25 & 14.67 & -0.684 & 0.001 \\
\hline S.C. leaf water (19) & -2.21 & -22.15 & -0.646 & 0.003 & & & & & \\
\hline $5 \mathrm{~cm}$ soil water & 0.88 & -32.89 & 0.379 & 0.021 & $5 \mathrm{~cm}$ soil water & -0.45 & -1.15 & -0.514 & 0.009 \\
\hline $10 \mathrm{~cm}$ soil water & 0.34 & -20.73 & 0.332 & 0.045 & $10 \mathrm{~cm}$ soil water & -0.54 & -0.16 & -0.589 & 0.002 \\
\hline Air moisture near the ground & 0.42 & 9.23 & 0.285 & 0.087 & & & & & \\
\hline Air moisture at the canopy & 0.31 & 12.28 & 0.173 & 0.305 & Air moisture at the canopy & 0.64 & 9.39 & 0.491 & 0.005 \\
\hline \multicolumn{5}{|c|}{ S4-Aug } & \multicolumn{5}{|c|}{ S5-Aug } \\
\hline P.E. leaf water & -4.40 & 2.274 & -0.642 & $<$ & R.S. leaf water & -1.82 & -158.14 & -0.742 & $<0.001$ \\
\hline S.A. leaf water & -2.15 & -64.28 & -0.560 & $<0.001$ & & & & & \\
\hline $10 \mathrm{~cm}$ soil water & 0.08 & -32.97 & 0.050 & 0.755 & & & & & \\
\hline Air moisture at the canopy & 0.54 & 0.95 & 0.773 & $<\mathbf{0 . 0 0 1}$ & Air moisture at the canopy & 0.83 & -18.23 & 0.684 & 0.001 \\
\hline
\end{tabular}

Table 9. Equations of soil water $\delta \mathrm{D}$ and $\delta^{18} \mathrm{O}$ at each site using the linear least squares fit method. Here, $r$ is the correlation coefficient, and $p$ is the significance level. $p<0.001$ indicates statistical significance at the $99.9 \%$ significance level, and $p<0.05$ indicates statistical significance at the $95 \%$ significance level.

\begin{tabular}{lrrrrrrr}
\hline Sites & Equation & $r$ & $p$ & Sites & Equation & $r$ & $p$ \\
\hline S1-Sep & $\delta \mathrm{D}=7.114 \times \delta^{18} \mathrm{O}+3.030$ & 0.921 & $<0.001$ & S3-Aug & $\delta \mathrm{D}=7.355 \times \delta^{18} \mathrm{O}-8.267$ & 0.914 & $<0.001$ \\
S1-Jun & $\delta \mathrm{D}=4.998 \times \delta^{18} \mathrm{O}-16.213$ & 0.825 & $<0.001$ & S4-Aug & $\delta \mathrm{D}=2.615 \times \delta^{18} \mathrm{O}-31.128$ & 0.890 & $<0.001$ \\
S2-Jun & $\delta \mathrm{D}=3.952 \times \delta^{18} \mathrm{O}-26.901$ & 0.888 & $<0.001$ & S5-Aug & $\delta \mathrm{D}=2.840 \times \delta^{18} \mathrm{O}-44.930$ & 0.642 & 0.222 \\
\hline
\end{tabular}

\subsection{Variations in $d_{\text {leaf }}, d_{\text {xylem }}, d_{\text {soil }}$ and $d_{\text {moisture }}$ under different conditions}

\subsubsection{Variations in d-excess in leaf water and xylem water and their diurnal patterns}

The significant differences in d-excess are found between leaf water and xylem water in both the upper reaches and the lower reaches. In order to evaluate the effect of plant transpiration on $d_{\text {leaf }}$, we calculate the difference between $d_{\text {leaf }}$ and $d_{\text {xylem }}$, assuming that $d_{\text {xylem }}$ represents the d-excess of source water. The differences in averaged $d_{\text {xylem }}$ and $d_{\text {leaf }}$ vary from 21.9 to $165.6 \%$, and the differences are $70.9 \%$ o in Q.S., $30.6 \%$ in P.F., $21.9 \%$ in P.V. and $36.6 \%$ in S.C. in the upper reaches, and $102.0 \%$ in P.E. and $165.6 \%$ in R.S. in the lower reaches (Table 4). These differences reach the maximum value in the afternoon (Fig. 4). Since no isotopic frac- tionation occurs during water uptake and transport from roots to twigs (Washburn and Smith, 1934), the large differences between $d_{\text {xylem }}$ and $d_{\text {leaf }}$ found in this study indicate that plant transpiration results in lower $d_{\text {leaf }}$ and releases water vapor with higher d-excess values into the atmosphere. These were consistent with those expected from the recycling of surface evapotranspiration (Gat et al., 1994). Therefore, mixing of transpiration moisture in the atmosphere will increase

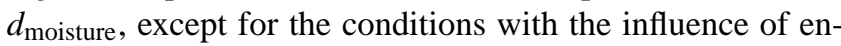
trained atmospheric moisture with high d-excess. In addition, during the sunny days, the clear and robust diurnal variations in $d_{\text {leaf }}$ with a daily maximum in the early morning and a negative peak in the mid-afternoon are found at all the study sites (Fig. 4 and Table 4), while no diurnal variations in $d_{\text {leaf }}$ are found on the cloudy days (Fig. 7). These results indicate that $d_{\text {leaf }}$ is affected by meteorological conditions through 

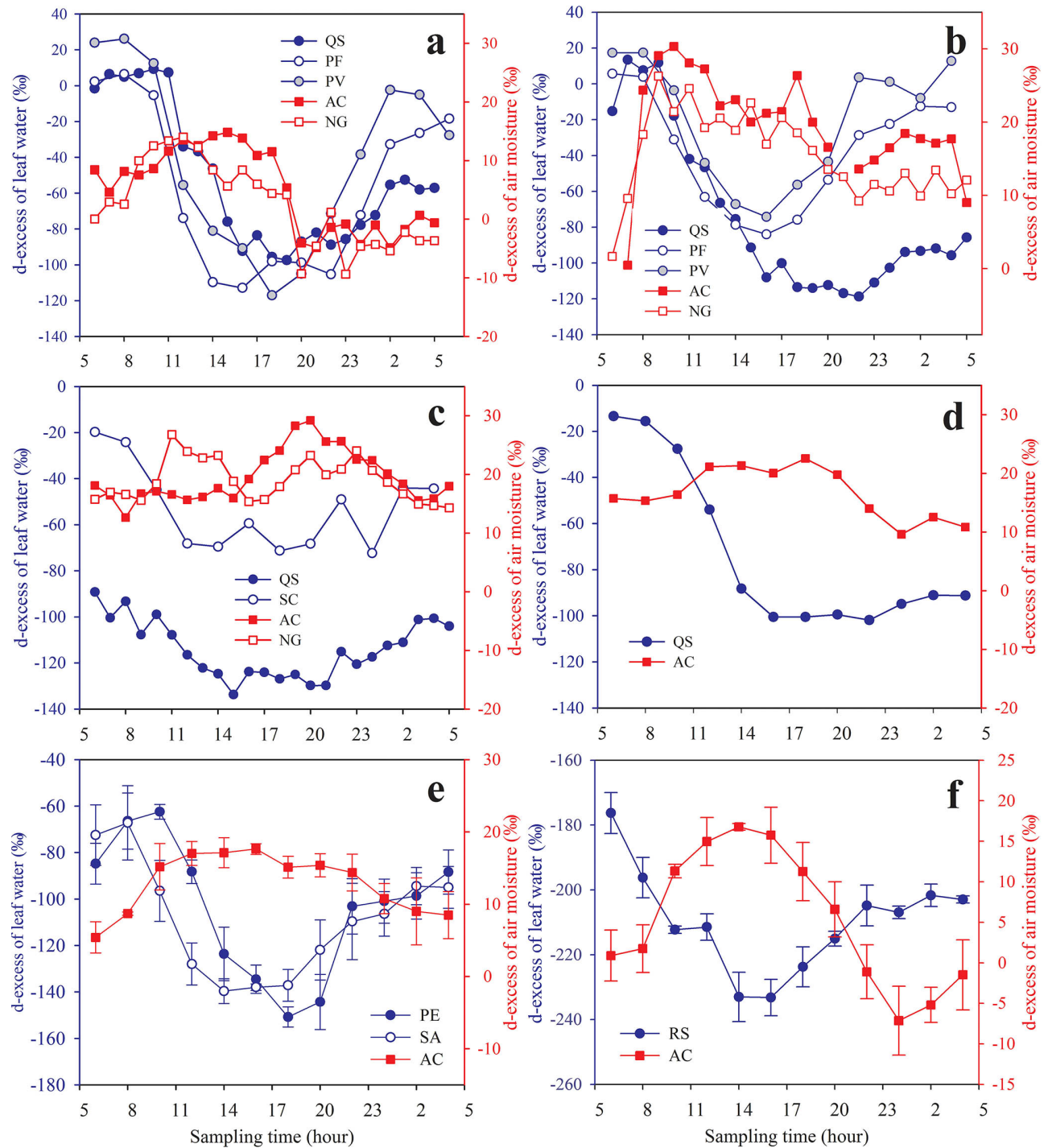

Figure 9. Comparison of leaf water and air moisture d-excess values during the sunny days. Note: panels (a), (b), (c), (d), (e) and (f) refer to the same locations as in Fig. 2, and the abbreviations of plant Latin names are the same as in Table 3. AC and NG refer to air moisture at the canopy level and near the ground, respectively.

their effect on plant transpiration. At the same time, no diurnal variations in the $d_{\text {xylem }}$ of all species are found on either the sunny or cloudy days (Figs. 4 and 7), indicating that $d_{\text {xylem }}$ is stable and that the effect of meteorological conditions on $d_{\text {xylem }}$ is small. These results also suggested that the d-excess of moisture through plant transpiration has an important role in changing the $d_{\text {moisture }}$ of local air moisture during the sunny days.

\subsubsection{Variations in d-excess in shallow soil water}

No clear diurnal trends in $d_{\text {soil }}$ are found, except at S3-Aug. At S3-Aug, there are clear daily variations in $d_{\text {soil }}$, which reaches the lowest value at around 12:00 and slowly climbs up to the previous level the next day (the first sunny day after a rain event) (Fig. 5d). This pattern is similar to $d_{\text {leaf }}$, which is likely due to the strong evaporation during the first sunny day after a rain event (rain stopped at about 22:00, and we started to take samples at 06:00 the next day) (Fig. 5d). At S3-Aug, during the first day after a rain event, we also found a negative relationship between $d_{\text {soil }}$ of $5,10 \mathrm{~cm}$ and $T$ (Table 8), and opposite patterns between the diurnal variations in $d_{\text {soil }}$ and $d_{\text {moisture }}$ (Fig. 10). These results indicate that the d-excess of moisture through soil evaporation also has an important role in changing the $d_{\text {moisture }}$ of local air moisture during the sunny day after the rain events. In addition, the effect of soil evaporation on $d_{\text {moisture }}$ is similar to the plant transpiration effect, and this effect was mainly controlled by temperature, 


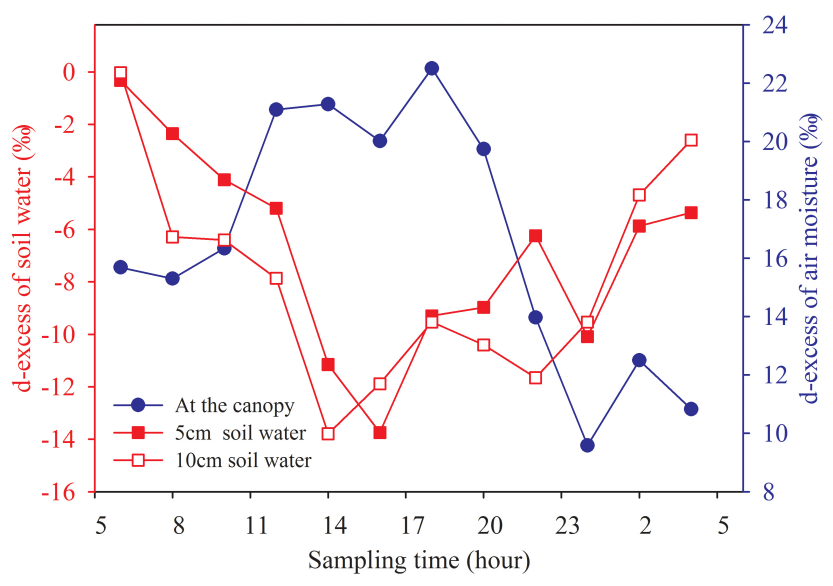

Figure 10. Comparison of soil water and air moisture d-excess values during the sunny days after the $4 \mathrm{~h}$ rain event on 2 August 2009 at S3-Aug.

as indicated by the negative relationship between $d_{\text {soil }}$ and $T$ (Table 8).

\subsubsection{Variations in d-excess in air moisture near the ground and at the canopy}

In our study, the peak-to-trough magnitudes vary greatly, and are $39.9 \%$ near the ground and $36.7 \%$ at the canopy in the upper reaches, and 17.3\%o (S4-Aug) and 30.6\%o (S5Aug) at the canopy in the lower reaches (Table 4 and Fig. 6). These observed values are higher than those of previous reports that the peak-to-trough magnitudes vary from 3.5 to $17.1 \%$ (Welp et al., 2012). The higher range is likely caused by the large diurnal $\mathrm{RH}$ range (an up to $80 \%$ change) in these environments. The lowest $d_{\text {moisture }}$ values are found near the ground $(1.5 \%)$ at high altitudes during September (S1Sep). The low values may be related to the atmospheric entrainment contribution, as atmospheric entrainment has been found to be responsible for the low d-excess values observed in the Pacific Northwest (Lai and Ehleringer, 2011).

In our study, during the sunny days, the $d_{\text {moisture values }}$ vary diurnally, showing a clear and robust pattern of the highest $d_{\text {moisture }}$ values at midday, and the lowest $d_{\text {moisture }}$ values at night at all the sites (Fig. 6). The same trends were also found in urban settings (New Haven and Beijing), agricultural settings (Rosemount and Luancheng), forest (Borden Forest) and grassland (Duolun) (Welp et al., 2012), at one Beijing site (Wen et al., 2010), and in the Pacific Northwest (Lai and Ehleringer, 2011). These results showed that $d_{\text {moisture }}$ diurnal variation is not a pattern unique to any particular location or vegetation type, and the diurnal pattern of $d_{\text {moisture }}$ may suggest that $d_{\text {moisture }}$ is not a conserved tracer of humidity conditions in the marine moisture source region (Welp et al., 2012), and is strongly controlled by local evaporation and transpiration.
There are no clear diurnal patterns of $d_{\text {moisture }}$ during the cloudy days when plant activity is low, which supports the role plants play in regulating $d_{\text {moisture }}$; namely, there are no clear diurnal variations for $d_{\text {moisture, except at S1-Jun }}$ (Fig. 8). The $d_{\text {moisture value at S1-Jun shows diurnal variation }}$ (Fig. 8b), which corresponds to patterns of $d_{\text {leaf }}$ after 08:00 (Figs. $7 b$ and 8b).

\subsection{The controlling factors of the d-excess of various pools}

\subsubsection{Correlations between $d_{\text {leaf }}$ and RH or $T$}

Significantly positive correlations are found between $d_{\text {leaf }}$ and RH at all the study sites during our study periods (from June to September) (Table 6). Significantly negative relationships are also found between $d_{\text {leaf }}$ and $T$, except in Q.S. at S1-Jun. In addition, during the sunny days, stronger relationships between $d_{\text {leaf }}$ and $T / \mathrm{RH}$ are found at all study sites (Table 7). These results suggest that meteorological conditions such as RH and $T$ have a strong effect on variations in $d_{\text {leaf }}$, likely through the effect on transpiration.

\subsubsection{Correlations between $d_{\text {soil }}$ and RH or $T$}

There are significant correlations between $d_{\text {soil }}$ and RH or $T$ in several cases. For example, the $d_{\text {soil }}$ of $10 \mathrm{~cm}$ is positively correlated with RH (Table 6), and the $d_{\text {soil }}$ of 5 and $10 \mathrm{~cm}$ are negatively correlated with $T$ (Table 8 ) at S3. The $d_{\text {soil }}$ of $10 \mathrm{~cm}$ is also positively correlated with RH (Table 6), and the $d_{\text {soil }}$ of $5 \mathrm{~cm}$ is negatively correlated with $T$ at S1-Sep (Table 8). At S3-Aug, during the first day after rain event, the negative relationship between $d_{\text {soil }}$ at 5 and $10 \mathrm{~cm}$ and $T$ (Table 8), the clear diurnal variations in $d_{\text {soil }}$ at 5 and $10 \mathrm{~cm}$ (Fig. 5d) and the opposite patterns between the diurnal variations in $d_{\text {soil }}$ and $d_{\text {moisture }}$ (Fig. 10), are found. These results indicate that the d-excess of moisture through soil evaporation also has an important role in changing the $d_{\text {moisture }}$ of local air moisture during the sunny days after the rain events, and this role is controlled by meteorological conditions. At the same time, the $d_{\text {soil }} / \mathrm{RH}$ are $0.08 \% \circ \%^{-1}$, and the $d_{\text {soil }} / T$ vary from -0.16 to $-0.54 \% 0^{\circ} \mathrm{C}^{-1}$, respectively, which are an order of magnitude lower than those of the $d_{\text {leaf }} / \mathrm{RH}$ (from 0.49 to $2.53 \% \%^{-1}$ ) and $d_{\text {leaf }} / T$ (from -6.74 to $-1.59 \% 0^{\circ} \mathrm{C}$ ). This means that even on the sunny day, the contribution of shallow soil water evaporation to $d_{\text {moisture }}$ is much less than that of plant transpiration (Tables 6 and 7).

\subsubsection{Variations in $d_{\text {moisture }}$ and its controlling factors}

The main moisture sources of local air moisture come from canopy transpiration, soil evaporation and atmospheric entrainment (Lai and Ehleringer, 2011). If $d_{\text {moisture }}$ is a conservative tracer of conditions in the moisture source region, we would not expect it to vary with local relative humidity unless there is a local source of moisture for 

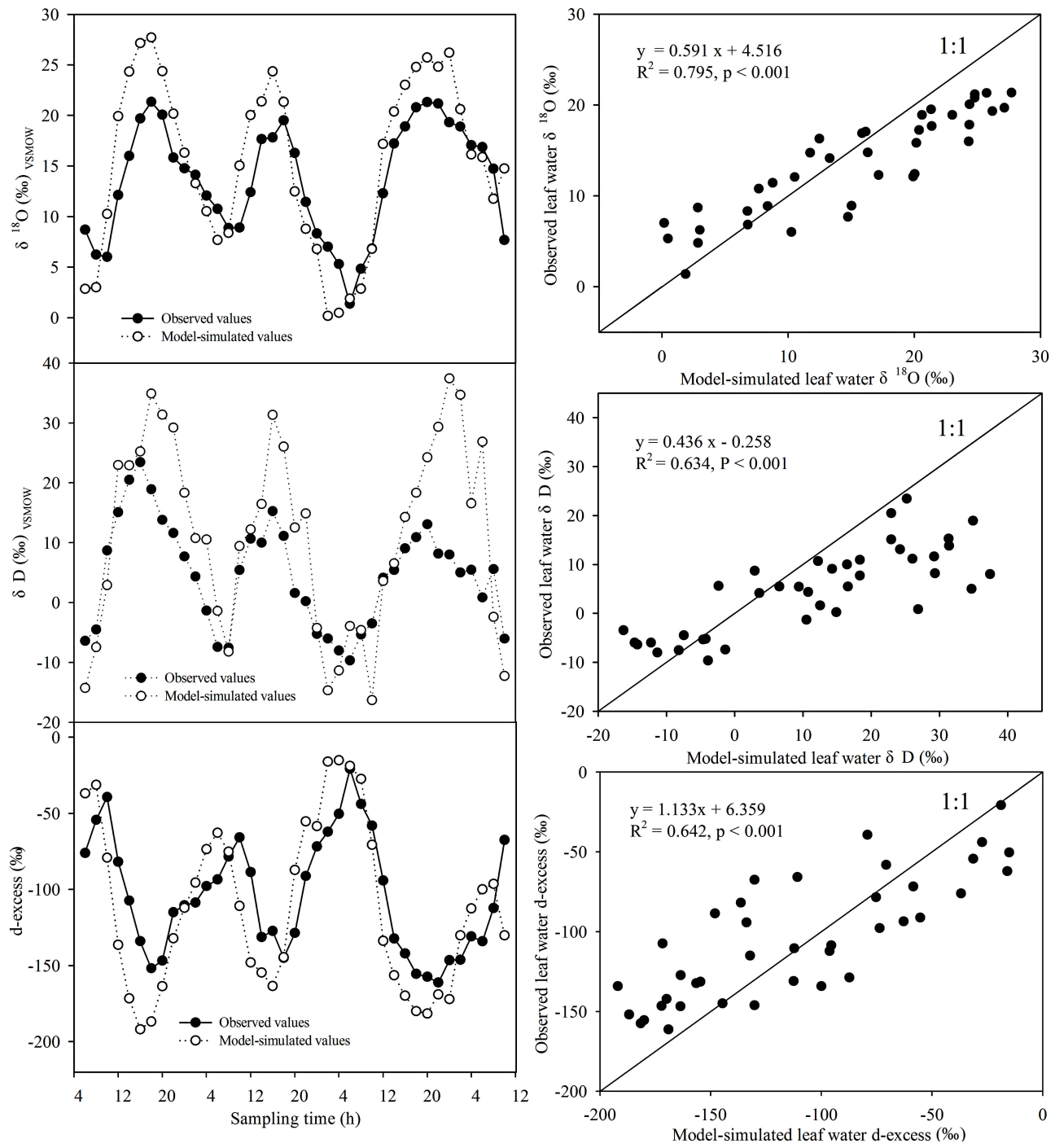

Figure 11. Comparison of leaf water $\delta^{18} \mathrm{O}, \delta \mathrm{D}$ and d-excess values for Populus euphratica between the simulated values (steady-state Craig-Gordon model) and observed values at S5-Aug.

the atmosphere (Welp et al., 2012). In our study, except near the ground at S1-Sep, significantly negative correlations are found between $d_{\text {moisture }}$ and $\mathrm{RH}$ at all the study sites. The mean $d_{\text {moisture }} / \mathrm{RH}$ is $-0.27 \% 0 \%^{-1}$, ranging from $-0.68 \% 0 \%^{-1}$ (S5-Aug) to $-0.13 \% 0 \%^{-1}$ (S4-Aug) (Table 6). Except at S5-Aug, the rates of $d_{\text {moisture }} / \mathrm{RH}$ of all the sites are lower than that of Merlivat and Jouzel's theoretical prediction $\left(-0.43 \% \circ \%^{-1}\right)$ (Merlivat and Jouzel, 1979) (Table 6). Aemisegger et al. (2013) reported the importance of continental moisture recycling. It concluded that the contribution of plant transpiration to the continental evaporation flux can be deduced from the $d_{\text {moisture }}-\mathrm{RH}$ relation at the seasonal timescale and for individual events (Aemisegger et al., 2013). The relationship between $d_{\text {moisture }}$ and RH strongly depends on the isotopic composition of the soil moisture and the contribution of transpiration, which can be assumed in first order to be non-fractionating over timescales of longer than 1 day (Harwood et al., 1999; Farquhar et al., 2007). Welp et al. (2012) also reported that afternoon averages (12:00-18:00 LST) of $d_{\text {moisture }}$ are correlated with RH at the New Haven $\left(d_{\text {moisture }} / \mathrm{RH}=-0.36 \% \%^{-1}\right)$ and Borden Forest $\left(d_{\text {moisture }} / \mathrm{RH}=-0.22 \% \%^{-1}\right)$ sites during the summer months (June-August). In addition, except at S2-Jun, there are significantly positive relationships between $d_{\text {moisture }}$ and $T$ at all the sites. The mean $d_{\text {moisture }} / T$ are $0.72 \% 0^{\circ} \mathrm{C}^{-1}$, varying from $0.54 \% 0^{\circ} \mathrm{C}^{-1}$ (S4-Aug) to $0.91 \% 0^{\circ} \mathrm{C}^{-1}$ (S1Jun) (Table 8). This is higher than that of Merlivat and Jouzel's theoretical prediction $\left(0.35 \%{ }^{\circ} \mathrm{C}^{-1}\right)$ (Merlivat and Jouzel, 1979). These results suggest that local contributions of moisture to $d_{\text {moisture }}$ are high, and that local meteorological conditions such as RH and $T$ have an important effect on $d_{\text {moisture }}$. In addition, during the sunny days, the clear diurnal 


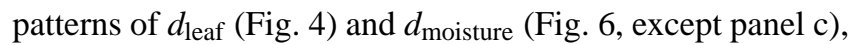
the opposite patterns between the diurnal variations in $d_{\text {leaf }}$ and $d_{\text {moisture }}$ (Fig. 9), and a significantly negative relationship between $d_{\text {moisture }}$ and $d_{\text {leaf }}(p<0.001)$ and highly significant relationships between $d_{\text {moisture }}$ and $\mathrm{RH} / T(p<0.001)$ (Tables 6,7 and 8 ) are found, suggesting that there is a strong linkage between $d_{\text {moisture }}$ and $d_{\text {leaf }}$, and that the regulation of plant transpiration on the variations in atmospheric vapor isotopic composition is strong.

\subsection{Comparison of modeled and observed leaf water $\delta^{18} \mathrm{O}, \delta \mathrm{D}$ and d-excess}

The modeling results reasonably captured the diurnal variations in $\delta^{18} \mathrm{O}, \delta \mathrm{D}$ and d-excess, with some discrepancies (Fig. 11). The discrepancies were larger for $\delta \mathrm{D}$ than for $\delta^{18} \mathrm{O}$. The results indicate that a better parameterization of $\delta \mathrm{D}$ or non-steady-state modeling is likely needed to simulate the dexcess dynamics in leaf water more accurately. The d-excess values of other components (e.g., soil water, atmospheric vapor) are rarely seen in the literature, and the current study provides a valuable source for validating the modeling work of the d-excess of various components.

\section{Conclusions}

Through extensive characterization of $\delta \mathrm{D}, \delta^{18} \mathrm{O}$ and d-excess in different water pools (e.g., leaf water, xylem water, 5 and $10 \mathrm{~cm}$ soil water and air moisture) in the HRB, we aimed to investigate the effects of local processes (e.g., plant transpiration and evaporation) on the d-excess variations in different water pools. We concluded the following:

1. There were significant variations in $\delta \mathrm{D}$ and $\delta^{18} \mathrm{O}$ in different water pools. The most negative $\delta \mathrm{D}$ and $\delta^{18} \mathrm{O}$ values were found in air moisture. The average $\delta \mathrm{D}$ and $\delta^{18} \mathrm{O}$ values of air moisture were -101.8 and $-14.1 \%$ o in the upper reaches and -124.4 and $-16.8 \%$ in the lower reaches, respectively. The most positive $\delta \mathrm{D}$ and $\delta^{18} \mathrm{O}$ values were found in leaf water. The average $\delta \mathrm{D}$ and $\delta^{18} \mathrm{O}$ values of leaf water were 0.9 and $8.1 \% o$ in the upper reaches and 6.6 and $18.2 \%$ in the lower reaches, respectively. The $\delta \mathrm{D}-\delta^{18} \mathrm{O}$ regression lines of leaf water, xylem water and shallow soil water deviated gradually from their corresponding LMWL with the increase in $T$ and the decrease in $\mathrm{RH}$.

2. Peak-to-trough amplitudes of $d_{\text {leaf }}, d_{\text {xylem }}, d_{\text {soil }}$ and $d_{\text {moisture }}$ varied from 52.6 to $147.2 \%$ o, 10.2 to $48.8 \%$, 25.7 to $51.6 \%$ and 17.3 to $39.9 \%$, respectively, which were an order of magnitude higher than previous observations and predications (e.g., Merlivat and Jouzel, 1979; Welp et al., 2012). The mean $d_{\text {moisture }}$ values were the most positive, which were $7.7 \%$ near the ground and $11.2 \%$ at the canopy level in the upper reaches,
12.8 and $5.6 \%$ at the canopy level at the riparian forest site and at the Gobi site in the lower reaches. The $d_{\text {leaf }}$ values were the most negative, which were $-41.1 \%$ in the upper reaches and $-145.0 \%$ in the lower reaches.

3. Several lines of evidence suggest that $d_{\text {moisture is not a }}$ conserved tracer of humidity conditions of the marine moisture source region, and is controlled by local transpiration and evaporation. The evidence includes the clear diurnal patterns of $d_{\text {moisture }}$ and $d_{\text {leaf }}$ during the sunny days, the strong correlations of $d_{\text {leaf }}$ with meteorological conditions ( $T$ and $\mathrm{RH}$ ), the significant correlations of $d_{\text {moisture }}$ with $d_{\text {leaf }}, T$ and RH, and no diurnal patterns of $d_{\text {moisture }}$ and $d_{\text {leaf }}$ during the cloudy days when plant activity was low. In addition, large differences between average $d_{\text {xylem }}$ and $d_{\text {leaf }}$ were observed in our study, indicating that the amount of d-excess lost through transpiration into the atmosphere was high. Our results indicate that plant transpiration strongly regulates $d_{\text {moisture }}$, especially during the sunny days. The effect is controlled by local meteorological conditions, such as $T$, radiation and $\mathrm{RH}$.

4. The influences of shallow soil water evaporation on

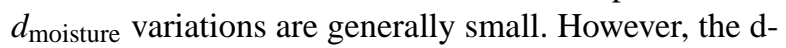
excess values of moisture from soil evaporation have a strong effect on $d_{\text {moisture }}$ on the first sunny day after a rain event. The size of this effect is related to $T$ and $\mathrm{RH}$.

5. The steady-state Craig-Gordon model can reasonably capture the diurnal variations in $\delta^{18} \mathrm{O}, \delta \mathrm{D}$ and d-excess with small discrepancies. Non-steady-state models are likely needed to simulate the d-excess dynamics of leaves and other components more accurately.

Our study shows that the $d_{\text {moisture }}$ of the surface air at continental locations can be significantly altered by local processes in both mountain areas (Qilian Mountains) and extremely dry environments (Ejin); therefore, such an effect is likely a universal phenomenon across regions with varying climates.

Acknowledgements. This research is supported by the National Science Foundation of China (grants 91325102, 91025016, 91125025 and 41261020) and the Hundred Talents program of the Chinese Academy of Sciences (no. 29Y127D11). It is also partially supported through an international development fund from Indiana University-Purdue University Indianapolis (IUPUI) and an NSF award to L. Wang (IIA-1427642). Special thanks to Fang Wang, Guobao Xu, Wenling An, Xiaomei Peng, Heng Wei, Wenzhi Wang and Xiaomin Zeng for field sampling and laboratory analyses. We are grateful for the comments from two anonymous reviewers; their comments significantly improved the readability and quality of the manuscript.

Edited by: F. Tian 


\section{References}

Aemisegger, F., Pfahl, S., Sodemann, H., Lehner, I., Seneviratne, S. I., and Wernli, H.: Deuterium excess as a proxy for continental moisture recycling and plant transpiration, Atmos. Chem. Phys., 14, 4029-4054, doi:10.5194/acp-14-4029-2014, 2014.

Allison, G. B.: The relationship between 180 and deuterium in water in sand columns undergoing evaporation, J. Hydrol., 55, 163169,1982

Brooks, J. R. E., Barnard, H. R., Coulombe, R., and McDonnell, J. J.: Ecohydrologic separation of water between trees and streams in a Mediterranean climate, Nat. Geosci., 3, 100-104, doi:10.1038/ngeo1722, 2010.

Brunel, J. P., Simpson, H. J., Herczeg, A. L., Whitehead, R., and Walker, G. R.: Stable isotope composition of water vapor as an indicator of transpiration fluxes from rice crops, Water Resour. Res., 28, 1407-1416, 10.1029/91wr03148, 1992.

Clark, I. D. and Fritz, P.: Environmental isotopes in hydrogeology, CRC press, New York, 1997.

Craig, H. and Gordon, L. I.: Deuterium and oxygen-18 variations in the ocean and marine atmosphere, in: Proceedings of the Conference on Stable Isotopes in Oceanographic Studies and Paleotemperatures, edited by: Tongiogi, E., 1-24, Cons. Naz. delle Ric., Rome, 1965.

Cuntz, M., Ogée, J., Farquhar, G., Peylin, P., and Cernusak, L.: Modelling advection and diffusion of water isotopologues in leaves, Plant Cell Environ., 30, 892-909, 2007.

Dalai, T. K., Bhattacharya, S., and Krishnaswami, S.: Stable isotopes in the source waters of the Yamuna and its tributaries: seasonal and altitudinal variations and relation to major cations, Hydrol. Process., 16, 3345-3364, 2002.

Dansgaard, W.: Stable isotopes in precipitation, Tellus, 16, 436468, 1964

Dawson, T. E.: Hydraulic lift and water use by plants: implications for water balance, performance and plant-plant interactions, Oecologia, 95, 565-574, 1993.

Dawson, T. E., Mambelli, S., Plamboeck, A. H., Templer, P. H., and Tu, K. P.: Stable isotope in plant ecology, Annu. Rev. Ecol. Syst., 33, 507-559, 2002.

Ehleringer, J. and Dawson, T.: Water uptake by plants: perspectives from stable isotope composition, Plant Cell Environ., 15, 10731082, 1992.

Farquhar, G. D., Cernusak, L. A., and Barnes, B.: Heavy water fractionation during transpiration, Plant Physiol., 143, 11-18, 2007.

Froehlich, K., Kralik, M., Papesch, W., Rank, D., Scheifinger, H., and Stichler, W.: Deuterium excess in precipitation of Alpine regions, Äìmoisture recycling, Isotopes in Environmental and Health Studies, 44, 61-70, 2008.

Gat, J., Bowser, C., and Kendall, C.: The contribution of evaporation from the Great Lakes to the continental atmosphere : estimate based on stable isotope data, Geophys. Res. Lett., 21, 557-560, 1994.

Gat, J.: Oxygen and hydrogen isotopes in the hydrologic cycle, Ann. Rev. Earth Planet. Sci., 24, 225-262, 1996.

Gong, J. D., Cheng, G. D., Zhang, X. Y., Xiao, H. L., and Li, X. Y.: Environmental changes of Ejina region in the lower reaches of Heihe River, Adv. Earth Sci., 17, 491-496, 2002.
Good, S., Soderberg, K., Wang, L., and Caylor, K.: Uncertainties in the assessment of the isotopic composition of surface fluxes: A direct comparison of techniques using laser-based water vapor isotope analyzers, J. Geophys. Res., 117, D15301, doi:10.1029/2011JD017168, 2012.

Harwood, K., Gillon, J., Roberts, A., and Griffiths, H.: Determinants of isotopic coupling of $\mathrm{CO} 2$ and water vapour within a Quercus petraea forest canopy, Oecologia, 119, 109-119, 1999.

He, J. Q.: The spatial and temporal variations of stable isotopes in precipitation and river water in the Hexi Inland Rivers Basins, A dissertation for the degree of Doctor of Philosophy of Chinese Academy of Sciences, 2011.

Helliker, B. R. and Richter, S. L.: Subtropical to boreal convergence of tree-leaf temperatures, Nature, 454, 511-514, 2008.

Jackson, R., Moore, L., Hoffmann, W., Pockman, W., and Linder, C.: Ecosystem rooting depth determined with caves and DNA, Proc. Natl. Acad. Sci., USA, 96, 11387-11392, 1999.

Karim, A. and Veizer, J.: Water balance of the Indus River Basin and moisture source in the Karakoram and western Himalayas: Implications from hydrogen and oxygen isotopes in river water, J. Geophys. Res.-Atmos., 107, ACH 9-1-ACH 9-12, 2002.

Kendall, C. and McDonnell, J. J.: Isotope tracers in catchment hydrology, Elsevier, Amsterdam, 1999.

Lai, C.-T. and Ehleringer, J. R.: Deuterium excess reveals diurnal sources of water vapor in forest air, Oecologia, 165, 213-223, doi:10.1007/s00442-010-1721-2, 2011.

Merlivat, L. and Jouzel, J.: Global climatic interpretation of the deuterium-oxygen 18 relationship for precipitation, J. Geophys. Res., 84, 5029-5033, doi:10.1029/JC084iC08p05029, 1979.

Newman, B. D., Breshears, D. D., and Gard, M. O.: Evapotranspiration partitioning in a semiarid woodland: ecohydrologic heterogeneity and connectivity of vegetation patches Vadose Zone J., 9, 561-572, doi:510.2136/vzj2009.0035, 2010.

Salati, E., Dall'Olio, A., Matsui, E., and Gat, J. R.: Recycling of water in the Amazon basin: an isotopic study, Water Resour. Res., 15, 1250-1258, 1979.

Soderberg, K., Good, S. P., O’Connor, M., Wang, L., Ryan, K., and Caylor, K. K.: Using atmospheric trajectories to model the isotopic composition of rainfall in central Kenya, Ecosphere, 4, 33 pp., doi:10.1890/es12-00160.1, 2013.

Sutanto, S. J., Wenninger, J., Coenders-Gerrits, A. M. J., and Uhlenbrook, S.: Partitioning of evaporation into transpiration, soil evaporation and interception: a comparison between isotope measurements and a HYDRUS-1D model, Hydrol. Earth Syst Sci., 16, 2605-2616, doi:10.5194/hess-16-2605-2012, 2012.

Uemura, R., Matsui, Y., Yoshimura, K., Motoyama, H., and Yoshida, N.: Evidence of deuterium excess in water vapor as an indicator of ocean surface conditions, J. Geophys. Res.-Atmos., 113, D19114, doi:10.1029/2008JD010209, 2008.

Wang, X. F. and Yakir, D.: Using stable isotopes of water in evapotranspiration studies, Hydrol. Process., 14, 1407-1421, 2000.

Wang, L., Caylor, K. K., Villegas, J. C., Barron-Gafford, G. A., Breshears, D. D., and Huxman, T. E.: Evapotranspiration partitioning with woody plant cover: assessment of a stable isotope technique, Geophys. Res. Lett., 37, L09401, doi:10.1029/2010GL043228, 2010. 
Wang, L., Niu, S., Good, S., Soderberg, K., Zhou, X., Xia, J., Sherry, R., Luo, Y., Caylor, K., and McCabe, M.: The effect of warming on grassland evapotranspiration partitioning using laser-based isotope monitoring techniques, Geochim. Cosmochim. Acta, 111, 28-38, doi:10.1016/j.gca.2012.12.047, 2013.

Wang, L., Good, S. P., and Caylor, K. K.: Global synthesis of vegetation control on evapotranspiration partitioning, Geophys. Res. Lett., 41, doi:10.1002/2014GL061439, 2014.

Washburn, E. W. and Smith, E. R.: The isotopic fractionation of water by physiological processes, Science, 79, 188-189, 1934.

Welp, L. R., Lee, X., Griffis, T. J., Wen, X.-F., Xiao, W., Li, S., Sun, X., Hu, Z., Val Martin, M., and Huang, J.: A metaanalysis of water vapor deuterium-excess in the midlatitude atmospheric surface layer, Global Biogeochem. Cy., 26, GB3021, doi:10.1029/2011gb004246, 2012.

Wen, X., Zhang, S., Su, X., Yu, G., and Lee, X.: Water vapor and precipitation isotope ratios in Beijing, China, J. Geophys. Res.Atmos., 115, D01103, doi:10.01029/02009JD012408, 2010.

Wenninger, J., Beza, D. T., and Uhlenbrook, S.: Experimental investigations of water fluxes within the soil-vegetation-atmosphere system: stable isotope mass-balance approach to partition evaporation and transpiration, Phys. Chem. Earth, 35, 565-570, 2010.
White, J., Cook, E., Lawrence, J., and Broecker, W.: The D/H ratios of sap in trees: implications for water sources and tree ring $\mathrm{D} / \mathrm{H}$ ratios, Geochim. Cosmochim., 49, 237-246, 1985.

Zhang, Y., Shen, Y., Sun, H., and Gates, J. B.: Evapotranspiration and its partitioning in an irrigated winter wheat field: A combined isotopic and micrometeorologic approach, J. Hydrol., 408, 203211, 2011.

Zhao, L., Yin, L., Xiao, H., Cheng, G., Zhou, M., Yang, Y., Li, C., and Zhou, J.: Isotopic evidence for the moisture origin and composition of surface runoff in the headwaters of the Heihe River basin, Chinese Sci. Bull., 56, 406-416, 2011a.

Zhao, L., Xiao, H., Zhou, J., Wang, L., Cheng, G., Zhou, M., Yin, L., and McCabe, M. F.: Detailed assessment of isotope ratio infrared spectroscopy and isotope ratio mass spectrometry for the stable isotope analysis of plant and soil waters, Rapid Commun. Mass Spectrom., 25, 3071-3082, 2011b.

Zhao, L., Xiao, H., Zhou, M., Cheng, G., Wang, L., Yin, L., and Ren, J.: Factors controlling spatial and seasonal distributions of precipitation $\delta^{18} \mathrm{O}$ in China, Hydrol. Process., 26, 143-152, doi:10.1002/hyp.8118, 2012. 